\title{
Od smutného Pierota k pyšnému vezírovi aneb Honzlovy České písně kramářské
}

\author{
From a Sad Pierrot to a Proud Vizier: \\ Honzl's Czech Broadside Ballads
}

Eva Šlaisová

\begin{abstract}
Abstrakt
Na začátku 40. let 20. století usiloval Jindřich Honzl o scénické zpracování lidového umění; dramatizoval a režijně upravil mnohé folklorní žánry, jako např. lidové písně, balady, dětská ř́kadla a hry. V souvislosti s Honzlovým zájmem o folklor má jedinečný význam pásmo České písně kramářské (1941), nebot' - přesto že mělo být prvním - zůstalo jediným realizovaným Honzlovým představením z této oblasti. Tato studie vychází z archivních materiálů, na jejichž základě autorka rekonstruuje tuto Honzlovu divadelní montáž a odhaluje, že obraz inscenace prezentovaný v odborné literatuře se v mnoha aspektech liší od pưvodní podoby. Studie představuje Honzlův inovativní př́stup ke kramářské písni (z hlediska výběru témat, písňové formy a inscenační praxe), jehož prostřednictvím se snažil upozornit na estetické kvality a sociální aspekt tohoto žánru, poukázat na paralely s moderním uměním a společenskou/politickou situací 40. let.
\end{abstract}

\section{Klíčová slova}

Jindřich Honzl, České písně kramářské, kramářská píseň, Divadélko pro 99, avantgarda, lidové divadlo, lidové umění, baroko, dramatická/divadelní montáž, divadlo za druhé světové války

\begin{abstract}
At the beginning of the 1940s, Jindryich Honzl inclined to Czech traditional folklore, such as popular songs, poetry, plays, theatre, children's games etc. These were intended for the Theatre for 99 (Divadélko pro 99), which he ran between the years 1939 and 1941. One of Honzl's most successful productions and, in fact, the only one that he staged from the area of folklore, was his dramatic montage Czech Broadside Ballads (České písně kramářské, 1941). In this montage, Honzl endeavored to change the common view of the broadside ballad as a clichéd, lowbrow artistic form, and to reveal its potential for contemporary art (theatre) as well as society.

Based on (recently discovered) archival materials, this study reconstructs Honzl's 1941 production of Broadside Ballads, and reveals that the image of the production presented in scholarly literature for decades is rooted in a book version of Czech Broadside Ballads from the 1960s, which does not faithfully reflect the original production. The study explores Honzl's innovative approach to the genre of the broadside ballad in terms of the selection of themes (ranging from sacral to profane, from intimate to social, etc.); forms (lyric, epic,
\end{abstract}


ballad); and staging practice, including montage, projections, puppet, and folk theatre; as well as the use of light and colours, motifs/leitmotifs, and metaphorical political allusions.

\section{Keywords}

Jindřich Honzl, Czech Broadside Ballads, broadside ballads, Theatre for 99, avant-garde, folk/ popular theatre, folk/popular art, Baroque, dramatic/theatrical montage, theatre during the Second World War

Tato studie vznikla jako součást výzkumu projektu GAČR Primitivní a lidové umění v české divadelní avantgardě: kontext, teorie, praxe (18-08260Y), který je řešen na Katedře divadelní vědy FF UK.

Počátek 40. let představuje pro Jindřicha Honzla novou tvůrčí etapu. Po období scénických proletářských recitací (20. léta), pokusech o uvedení principů dada, poetismu a surrealismu na českou divadelní scénu (20.-30. léta), spolupráci s Jiřím Voskovcem a Janem Werichem na jejich autorských hrách a filmech (30. léta) usiluje o scénické zpracování lidového umění. V této době dramatizoval a režijně upravil mnohé folklorní žánry, jako např. kramářské písně, balady, říkadla, dětské hry nebo písně, ale i výroční a rodinné obřady a národopisné zápisy Boženy Němcové, Františka Vaváka a dalších sběratelů. Dále vytvořil scénáře k národopisným filmům ${ }^{1}$ a teoreticky se zabýval lidovým uměním. ${ }^{2}$

V souvislosti s Honzlovým zájmem o folklor má jedinečný význam pásmo České písně kramářské $(\check{C} P K)$, nebot - přesto že mělo být prvním - zůstalo jediným realizovaným Honzlovým představením z této oblasti. ČPK měly premiéru 8. března $1941 \mathrm{v}$ Divadélku pro 99 a v přepracované podobě pod názvem Ty, který tu zpíváš nyni se krátce objevily na repertoáru Studia Národního divadla v roce 1946 (premiéra 7. května). ${ }^{3}$ V rukopise se ještě uchoval druhý a třetí díl Českých pisni kramářských, které nebyly nikdy uvedeny, ani knižně publikovány. ${ }^{4}$

1 Scénáře k národopisným filmům o svatbách jsou uloženy v Honzlově pozůstalosti, dále jen PJH (PJH 111/111d). Při jejich tvorbě Honzl vycházel z dramatické montáže Svatby, z níž si vypůjčil některé pasáže.

2 Mezi jeho studie etnograficky zaměřené patřri nap̌r. „Lidové divadlo“ (1937), „Objevné divadlo v lidovém divadle českém a slovenském“ (1940), „České písně kramářské v Divadélku pro 99“ (1941), „Obřad a divadlo“ (1946), rukopisné poznámky o folkloru (PJH 111/111d) nebo o obřadu (PJH 29d/029d-VI).

3 Pásmo Ty, který tu zpivaáš nyni bylo dedikováno Zdeňku Stránskému, herci D 99, který padl během pražského povstání 7. května 1945. Od původní podoby se pásmo lišilo hereckým obsazením, výběrem a uspořádáním písní, změnami v textech komentátora, volbou diapozitivů (např. byly promítnuty dva diapozitivy s fotografií Stránského, které nahradily původní diapozitivy s obrazy Smrtek - viz níže), přidáním Stránského básně Březen 1940 atd. Podle jedné z recenzí inscenace nedosahovala kvalit $\breve{C} P K$, hlavně kvůli rozsáhlým partům komentátora a recitaci / zpěvu některých herců (-a- 1946).

4 Strojopis s rukopisnými poznámkami je uložen v Honzlově pozůstalosti (PJH 23a/023I-PK). Oproti prvnímu dílu, který nabízí prưřez tématy kramářských písní, se druhý a třetí díl zaměřuje na téma jediné, jímž je válka. Rozdělen je na sedm částí: Odvod, Život v kasárnách, Bude vojna bude atd. Výběrem tématu se zde nabízí souvislost s Vojnou (1935) E. F. Buriana. 
Tato studie je pokusem o rekonstrukci $\check{C} P K$ z roku 1941 a jejím záměrem je revidovat stávající představu o této inscenaci, jak ji známe z dostupných publikací (BERÁNEK 1961; OBST 1964; BRABEC 1983; SRBA 1988; ŽDYCHOVÁ 2012). Při rekonstrukci budu vycházet převážně z režijních knih Jindřicha Honzla, knihy pro osvětlovače a dalších dobových materiálů, jako jsou programy, divadelní cedule, recenze, Honzlův článek věnovaný kramářským písním atd. (PJH 23a/023a-IIb, 23a/023a-IIc, 23a/023a-IId, 49/049II-režie, 23a/023-VI, 23/023-II, 26b/ 026b; HONZL 1964a). Důležitým pramenem jsou nově nalezené diapozitivy, které byly promítány během ČPK a jež umožňují rekonstrukci jednoho - dosud nepopsaného - plánu představení, a fotografie z inscenace pořízené Alexandrem Paulem (AAP 39372/1-9). ${ }^{5}$

\section{České písně kramářské v edicích Orbisu: problémy a nejasnosti}

Základním zdrojem informací o podobě Honzlovy montáže jsou dva výbory nakladatelství Orbis: Divadlo poezie a Divadélko pro 99, v němž se ČPK objevují v přetisku (BERÁNEK 1961; OBST 1964). Přestože antologie sledují odlišné cíle, ${ }^{6}$ obě se snaží co nejvěrněji zprostředkovat čtenářům způsob, jakým Honzl koncipoval své pásmo, upravoval a inscenoval texty písní. Při porovnání s archivním materiálem nicméně dojdeme ke zjištění, že podoba ČPK, kterou výbory vytvářejí, se liší od podoby, v jaké byly inscenovány v roce $1941 .^{7}$

První odlišnost pramení z rozdílné posloupnosti písní. Editoři knižního vydání se drželi řazení písní v režijní knize (PJH 23a /023a-IIb:10), ale nebrali v potaz Honzlovy rukopisné poznámky vepsané do knihy určující inscenační pořadí písní v pásmu, jak jej dokládá i program k premiéře z roku 1941 a recenze Zdeňka Nejedlého (PJH 23/023aIV; NEJEDLÝ: 1941).

\section{Uspořádaní písní ve výborech:}

Př́kladná píseň o smrti člověka

Písnička kratochvilná o těch sedlácích

Truchlivá novina o letošním pamětihodném povodní

5 Tímto bych chtěla vyjádřit poděkování Zitě Skořepové Honzlové, pravnučce Jindřicha Honzla, která spravuje režisérovu pozůstalost, za ochotu, s níž mi poskytla potřebné materiály z rodinného archivu. Zejména bych jí chtěla poděkovat, že vyslyšela mé prosby o pátrání po diapozitivech k ČPK, prohledala Honzlovu pozůstalost a našla (na půdě) kompletní sérii diapozitivů k tomuto pásmu (diapozitivy nejsou zahrnuty v soupisu pozůstalosti, jsou uloženy ve fondu Diapozitivy - Negativy 2, prozatím jim nebylo přiděleno evidenční číslo). Dále bych chtěla poděkovat Marcele Stránské a Alexandru Paulovi ml., již spravují archiv Alexandra Paula, za vyhledání a digitalizaci diapozitivů zachycujících různé aspekty inscenace ČPK.

6 Každá z publikací vřazuje Honzlovo pásmo do jiného kontextu. První jej vnímá v souvislosti s divadlem poezie, jejž se editoři na příkladech různých autorů (Jindřich Honzl, Václav Vaňátko nebo Jaroslav Dudek) snaží charakterizovat. Druhá se snaží představit specifika Honzlovy tvorby v Divadélku pro 99 a začlenit ji do divadelní historie.

7 Editoři Divadla poezie uvádějí, že pásmo pro ně sestavil Jindřich Honzl. Pokud tomu tak skutečně bylo, zůstává otázkou, proč se nedržel podoby, ve které ji ve 40 . letech představil na jevišti. 
Světská píseň mládencům a pannám

Zdaliž jsem ve snách byl ${ }^{8}$

Lamentací tureckého vezíra

Novina velmi žalostná, která se stala s jednou paní

Píseň ke cti a chvále blahoslavené Panny Marie častochovské

Nová píseň bohatým rodičům

Nová píseň na příklad mládencům a pannám. Jedna, dvě, tři ...

\section{Podle programu k Českým písním kramářským bylo jejich pořadí následovné:}

Příkladná píseň o smrti člověka

Novina velmi žalostná, která se stala s jednou paní

Píseň ke cti a chvále blahoslavené Panny Marie

Nová píseň všem bohatým rodičům

Nová píseň na příklad mládencům a pannám

Přestávka

Písnička kratochvilná o těch sedlácích

Truchlivá novina o letošním pamětihodném povodní

Lamentací tureckého velkého vezíra

Míchanice aneb žertování

Z porovnání je patrné, že edice se od původní podoby nelišily pouze uspořádáním písní, ale i jejich výběrem. Do scénické montáže nebyla zařazena dvě lyrická čísla „Píseň světská mládencům a pannám“ a „Světská píseň mládencům a pannám pro obveselení mysle [...]“ (SMETANA a VÁCLAVEK 1937: 115-116, 111-114). Pásmo měla dále uzavírat píseň „Míchanice“ (SMETANA a VÁCLAVEK 1937: 213-215). Vzhledem k tomu, že se o ní nezmiňuje žádná z recenzí (ani Nejedlého, který ve své kritice popisuje píseň po písni v chronologickém sledu) a že se neobjevuje v žádném strojopise/rukopise ČPK, lze se domnívat, že do pásma nebyla zařazena. ${ }^{9}$

Editoři dále nerespektovali Honzlovy úpravy písňových textů a škrtů v nich. Z jeho režijní knihy je zřejmé, že po sestavení pásma eliminoval některé popisné pasáže komentátora a lyrické, enumerační pasáže písní. Dále měnil pořadí slok, upravoval verše (např. kombinoval několik veršů z různých slok do jediné) nebo měnil slova, akcentoval určité významy a vytvářel významové napětí mezi sousedními jednotkami (slovy, verši, obrazem a slovem apod.). ${ }^{10}$

8 Píseň je uvedena ve výboru bez názvu. „Zdaliž jsem [...]“ je incipit. Její název zní „Píseň světská mládencům a pannám pro obveselení mysle a ukrácení času na světlo vydaná“ a je převzata z edice České pisně kramářské (SMETANA a VÁCLAVEK 1937: 111-114).

9 Podle dochované cedule (PJH 26b/026b-VI) se knižní edice v řazení a výběru písní liší i od Ty, který tu zpíváš nyni.

10 Např. úvodní píseň o smrti člověka Honzl oproti originálu výrazně zkrátil a změnil pořadí slok. Vypustil tři sloky (pátá a šestá se neobjevují v režijní knize, čtvrtá je v knize přeškrtnuta), ve kterých se mluví o vojně (tj. válce), a sedmou strofu, která válečné téma v jistém smyslu uzavírá, přesunul na závěr písně. Přesunem sloku osamostatnil, vytrhl z kontextu války, což Honzla vedlo k úpravě některých lexikálních jednotek, a učinil z ní dialog s komentátorem. Komentátor vybízí Smrt: „Poshov, Smrti - zastav zpěvačko! 
Výbory dále nereflektují Honzlovy inscenační úpravy textu (rozdělení mezi postavy, vypravěče) a scénické poznámky informující o scénografii, kostýmu, pohybu postav po jevišti, jejich mimice, gestech, způsobu provedení písně (recitace vs. zpěv, síla a tempo hlasového projevu apod.). Scénické poznámky, které se v edicích ČPK objevují, nejsou přepisem Honzlových instrukcí z režijních knih, ale jejich zjednodušením. ${ }^{11}$

Torzovitost výborů ve vztahu $\mathrm{k}$ inscenačnímu celku doplňují vzpomínky Antonína Dvořáka, který působil v D 99 jako osvětlovač, a herce Stanislava Vyskočila (účinkoval v D 99 i ve Studiu ND). Jejich popis je cenným zdrojem informací o scénickém provedení kramářských písní, nicméně oba jsou ve svém popisu selektivní, jak ve výběru písní, tak ve výběru detailů. Jejich vzpomínky se nadto v některých případech liší od informací zprostředkovaných archivním materiálem. ${ }^{12}$

$\mathrm{Z}$ výše uvedeného je zřejmé, že edice nezachycují věrně podobu inscenace a že mnohé její aspekty jsou dosud neznámé. Studium archivních materiálů nám umožňuje stávající představu korigovat a doplnit.

\section{České písně kramářské v D 99}

České písně kramářské byly poslední inscenací Divadélka pro 99, které Honzl mezi lety 1939 a 1941 provozoval v Topičově salonu na Národní tř́íě. Topičův salon byl suterénní výstavní sál s miniaturním jevištěm a hledištěm a skromným technickým vybavením, což Honzla vedlo $\mathrm{k}$ tomu, že základem svých inscenací učinil recitaci textů (které nespadaly do oblasti klasické dramatiky, jako např. poezie, dopisy, zvykoslovný materiál, úryvky z odborných textů apod.) hudbu a projekci. Z integrace těchto tří složek vznikly

Nechci být ošizen o tu sloku, kterou jste zamlčela. Zazpívejte ještě, spustte nápěv, který se tak líbí chudákům, zpívá se tam o šlechtických pánech a začíná to, ... nebude smilování, na dvě strany rozdělení“ (PJH 23a/023aIIb: 6). Na toto vybídnutí Smrt odpovídá právě sedmou slokou, jíž informuje komentátora, že ani on její moci neunikne; tím píseň končí. Pro porovnání uvádím komentátorův text z edic: „Poshov, Smrti - zastav zpěvačko! Jen chvíli ještě, než se rozhodnou [sic - rozhodnu]. Nechystám se zemřít, ne, držím v ruce groš, abych si koupil tvou píseň, paní, ale chci dobré zboží za své peníze, nechci být ošizen o tu sloku, kterou tiskař vysázel, ale kterou jste zamlčela. Zazpívejte ještě, prodáte snad více, spuste nápěv, který se tak líbí chudákům, zpívá se tam o šlechtických pánech a začíná to, ... nebude smilování, na dvě strany rozdělení ““ (HONZL 1964b: 70). Text působí zbytečně rozvlekle a rozmělňuje významové zvraty mezi replikami Smrti a komentátora. Patrně z tohoto důvodu Honzl komentátorův part zkrátil a vyškrtl z něj části, které dialog se Smrtí retardují.

11 Např. poznámky k písni o sedlácích jsou v edicích následující: „Na jevišti jsou dva robotníci. Sedí unaveni, jeden z nich se opírá o stůl. Před sebou mají džbánky.“ (HONZL 1964b: 72). Honzlova poznámka k písni zní: „[...] kostýmy selské otrhané, hospodský věnec, stůl, dvě židle dva džbánky. Zpěv: modré světlo, opona. Dva muži na jevišti pijí, zpěv tř̌́ žen jako ve třetí písni. Ženy přicházejí na jeviště, zastaví [se]. Sedlák - opřen pěstí o čelo - zpívá tiše k sedláku.“ (PJH PJH 23a/023a-IIb: 10).

12 Např. Dvořák i Vyskočil popisují v souvislosti s původní inscenací píseň „Tygr, ten jest přeukrutné zvíře“, která, jak již bylo řečeno výše, netvořila její součást; objevuje se až v novém nastudování pro Studio ND (DVOŘÁK 1964: 220; VYSKOČIL 1961: 169). Dalším příkladem může být popis diapozitivu, který Vyskočil zmiňuje v souvislosti s písní o Panně Marii. Údajně se mělo jednat o diapozitiv srdce probodnutého sedmi meči, nicméně v Honzlově pozůstalosti se dochoval diapozitiv se srdcem probodnutým šípem a řezaným pilou umístěným nad mužskou a ženskou dlaní (VYSKOČIL 1961: 170). Během písně byly nadto promítnuty i další diapozitivy, o kterých se Vyskočil nezmiňuje. 
nejprve večery poezie (např. Večer s Vitězslavem Nezvalem, Poezie 1900, Cizinci o Praze), později dramatické montáže Román lásky a cti, Dvě lásky Mikoláše Alše a České písně kramářské, představující vrchol Honzlovy válečné tvorby (více o D 99 např. OBST 1964; SRBA 1988).

ČPK Honzl reagoval na dobovou - ustrnulou - představu o jarmareční písni jako senzacechtivém dryáčnickém písňovém zpravodajství a na stereotypní způsoby jejího inscenování (parodování) na šantánových a kabaretních scénách (HONZL 1964: 65). Jeho záměrem bylo „ukázat, že poezie nemůže chybět žádnému projevu, který je skutečně lidový, [chtěl] pomoci poezii, aby zjevila svou přítomnost“ (HONZL 1964: 65). To bylo podle jeho názoru možné jen tehdy, ukáže-li se kramářská píseň, „V nových poměrech a v nových vztazích, jakoby v novém osvětlení, jakoby v mikroskopickém zvětšení, jakoby na novém pozadí“ (HONZL 1964b: 66). Jinými slovy, Honzl se domníval, že kramářské písně mají svou estetickou a společenskou hodnotu. Její odhalení, „zjevení“, není možné otrockým napodobováním či parodizováním jarmarečních písní, ale jejich vytržením z prostředí automatizovaného (ustrnulého) vnímání/prezentace a tvůrčím přepracováním na moderní divadelní scéně.

Východiskem Honzlova pásma byly dvě antologie: České pisně kramářské (1937) muzikologa Roberta Smetany a estetika a literárního historika Bedřicha Václavka (v typografické úpravě Karla Teigeho), z níž si Honzl vypůjčil název pro své pásmo, a Špaliček pisniček jarmarečnich (1940) sestavený a okomentovaný knihovníkem Národního muzea a literárním historikem Miloslavem Novotným (s ilustracemi Jindřicha Štyrského). Tyto antologie nejen prezentovaly rozsáhlý písňový korpus, ze kterého Honzl mohl vyjít při tvorbě pásma, ale také představovaly zásadní změnu v nazíraní na kramářskou píseň. Ukazovaly, že se nejedná pouze o dryáčnické zpravodajství, ale že kramářská píseň představuje rozmanitý a bohatý žánr co se týče tématu (víra, láska, vojna, válka, sociální poměry, vraždy, katastrofy atd.) i formy (lyrika, epika, balady) a že je důležitým dokladem jazykovým a kulturně historickým. ${ }^{13}$

$\mathrm{Z}$ antologií Honzl převzal devět písní, které tematicky uspořádal do dvou bloků zachycujících svět lidu v dichotomii posvátného a profánního. V prvním bloku byly představeny písně duchovní a milostné (propojené na základě barokní mystické erotiky), v druhém písně sociálního charakteru.

Nositelem textu byla postava zpěváka, který se v různé formě objevoval v každé písni, a/nebo dramatická postava, jež byla zhmotněním postavy tradičně namalované na obrázkové tabuli. Obrazovou tabuli v konvenční podobě v Honzlově pásmu nenalezneme, nahradil ji projekcí diapozitivů, stínohrou a divadelními výstupy herců.

Další součástí kramářské písně (resp. její tištěné podoby), kterou Honzl inscenoval originálním zpo̊sobem, byl novinový úvod, jehož funkcí bylo kontextualizovat píseň, podávat faktické údaje o událostech, a tím zvyšovat autenticitu písně a upoutat zájem

13 Za zmínku stojí, že Smetanova - Václavkova sbírka vyšla v edici Stezky, redigované Janem Mukařovským, jež si kladla za cíl „podávati dokumenty estetického tvoření v nejširším slova smyslu a upozorňovat na opomíjené a odlehlé oblasti estetična“ (Stezky 1937). V rámci této edice bylo publikováno např. i Bogatyrevovo Lidové divadlo české a slovenské, Čapkovo Uměni přirodních národů nebo Oberpfalcerovo Přiznání na mučidlech: texty ze starých knih černých. 
kupujících diváků. Funkci úvodu převzal v pásmu komentátor spojující jednotlivé písně, jehož výstupy byly založené na koláži citací a parafrází z odborné literatury, převážně z oblasti historie, a z Honzlových interpretací doby a písní. I jeho funkcí bylo kontextualizovat písně, ale také vysvětlovat specifika a historii tohoto žánru a rovněž nabízet jinou perspektivu na téma písně. Často se jednalo o pohled faktografický, „oficiální“, jehož prostřednictvím Honzl vytvářel komplexnější, ale i kontrastnější obraz skutečnosti.

Inovativně přistupoval Honzl i k hudbě. Z dochovaných partitur v jeho pozůstalosti lze vyčíst, že některé texty byly doprovázeny kramářskými melodiemi, převzatými z výše zmíněných antologií a upravenými skladatelem Jarmilem Burghauserem. ${ }^{14} \mathrm{Z}$ režijních knih a dobových recenzí se dozvídáme, že po každé písni následovala hudební mezihra, která jednotlivé výstupy pásma spojovala (PJH 23a/023a-IIb; NEJEDLÝ 1941; mat: 1941). V inscenaci dále Honzl nepoužil typické jarmareční hudební nástroje (flašinet, housle nebo akordeon), ale klavír.

$\mathrm{Z}$ variací těchto pěti prvků (textu písně, zpěváka, obrazové tabule, novinové zprávy o události a hudby), z jejich konfrontace, polarizace, ale i harmonizace a sjednocování sestavil Honzl své pásmo.

\section{La Parade}

ČPK začínaly údery na gong a promítnutím diapozitivu s obrazem Honoré Daumiera La Parade (1865-1868), který zachycuje smutného klauna - Pierota s bubnem stojícího, bez př́izně publika, před portrétem korpulentní ženy, ke kterému se tiskne druhý klaun.

Obraz mohl zaujmout Honzla jarmareční scénou, která zapadala do kontextu pásma, ale i tématem, jímž bylo umění a artisti z periférie jak umělecké, tak sociální. ${ }^{15}$ Lze předpokládat, že obraz vzbudil Honzlův zájem i svým politickým podtextem (kritikou expansivity Pruska vưči Francii), jenž rezonoval v českém prostředí. ${ }^{16}$

Ve chvíli, kdy se na scéně objevil komentátor a začal představovat první píseň pásma, obraz Pierota zmizel. Podle Vyskočilových vzpomínek byl komentátor oblečený do večerního obleku (smokingu), jako kabaretní konferenciér, a „na hlavě měl bílou čepičku s rolničkou jako Kašpárek“ nebo též jako Pierot (VYSKOČIL 1961: 171). Oblekem zdůrazňoval Honzl sounáležitost komentátora s postavami „prostředníků“,

\footnotetext{
14 Některé notace se dochovaly v Honzlově pozůstalosti (PJH 23a/023a-II).
}

15 Periferní charakter Pierotova výstupu je podržen vystoupením jiné skupiny artistů obklopené publikem, které je možno vidět v pozadí. Tento výjev je zmenšeninou jiného - stejnojmenného Daumierova obrazu.

16 Dáma na obraze a druhý klaun jsou dáváni do souvislosti s Daumierovými politickými litografiemi reflektujícími dobový prusko-francouzský konflikt. Žena je vnímána jako parafráze Daumierovy litografie Prusko (Prusse Colosse, 1866) zobrazující pruského císaře jako korpulentní dámu v šatech stejného střihu jako má dáma v La Parade. Druhý klaun stojící v pozoru nápadně připomíná Daumierovu kresbu Mars (publikovanou v časopise Charivari v roce 1868) představující karikaturu vojáků, tzv. „carmagnole“ (bojujících původně za Napoleona I.), jejichž znovuobjevení během prusko-francouzské krize Daumier karikoval. Podle Bruce Laughtona se Daumier snažil La Parade (a kresbami) upozornit Francouze na rozpínavost Pruska a varovat před hrozící válkou s Německem (LAUGHTON 1996: 135). 
Eva Šlaisová

Od smutného Pierota k pyšnému vezírovi aneb Honzlovy České písně kramářské

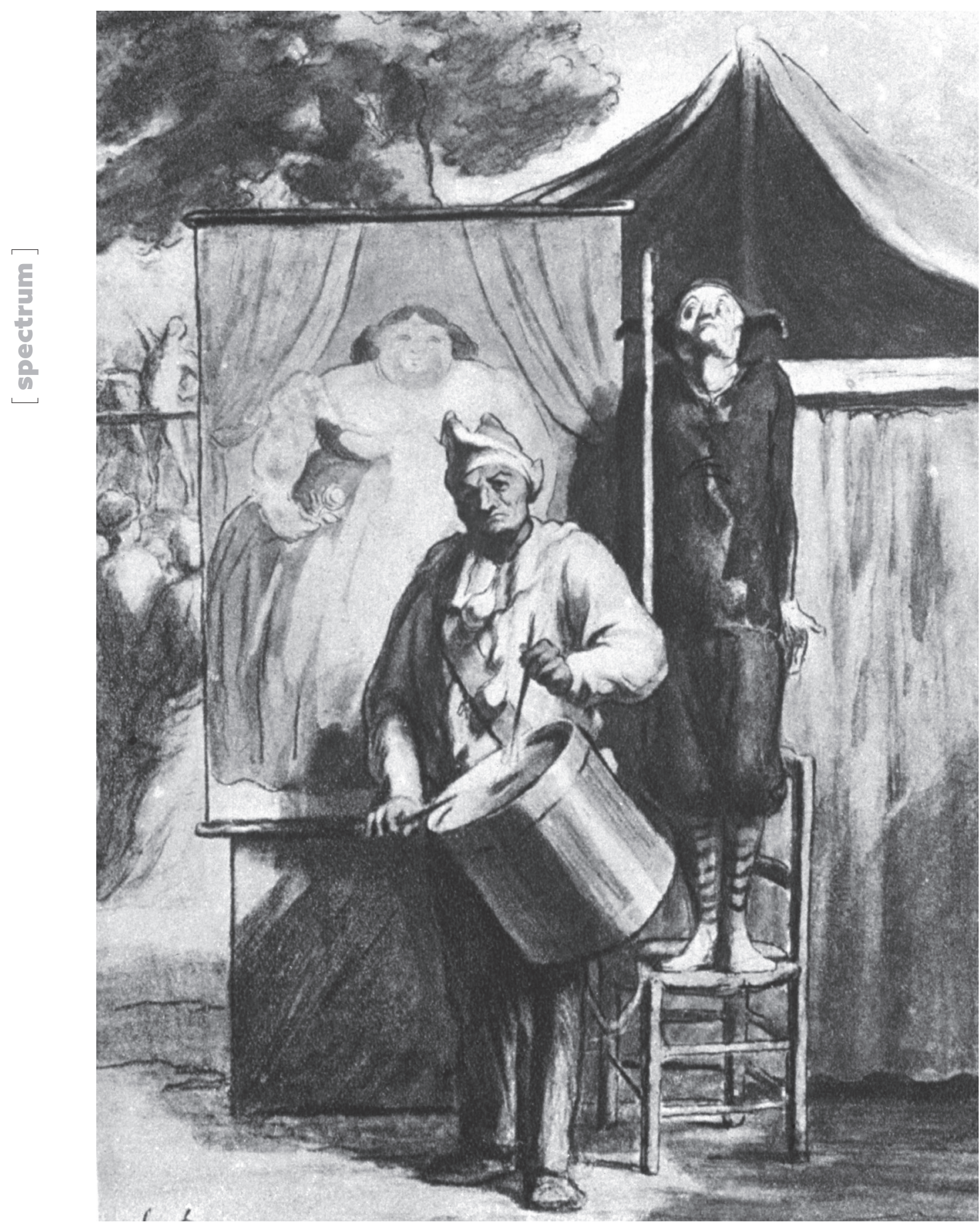

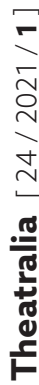

Obr. 1: Honoré Daumier, La Parade (dp. č. 1, PJH) 
kromě tří výše zmíněných i jarmarečního zpěváka či opovědníka v lidovém divadle, jejichž funkcí bylo navazovat kontakt s publikem a komentovat představení/vystoupení.

\section{Barokní eschatologický triptych}

První tři písně pásma zachycovaly rưzné aspekty religiozity českého lidu v 17. a 18. století. Honzl je koncipoval v souladu s barokními cykly (kancionály) eschatologických písní obsahujícími píseň o smrti (Totentanz), o posledním soudu, o pekelných mukách a nebeské slávě, jež se (znovu) objevily v českém kulturním prostoru v polovině 30 . let. ${ }^{17}$

Tématem první písně s názvem „Příkladná píseň o smrti člověka [...]“ a komentáře, který ji předcházel, byla Smrt a její různé podoby. Komentář byl rozdělen do dvou kontrapunktických odstavců. První představoval Smrt „barokní šlechty a jejího vznešeného umění,“ která, jak píše Honzl, „obnažuj[e] své hnisavé maso“. Druhý odstavec kladl do kontrastu smrt u lidu: „prost[ou] žen[u] v kanafasové sukni a soukenné jupce“ (HONZL 1964b: 67). Tento popis anticipoval podobu postavy Smrti v samotné písni, která kromě kanafasové sukně a režné blůzy měla na hlavě nasazenou papírovou masku s namalovanou Smrtkou a v ruce držela papírovou kosu (Obr. 7 a 8). Takto pojatá postava Smrti odkazovala k lidovým obřadům a hrám koncipovaným jako „hra na“, zde tedy jako hra na Smrt.

Výklad komentátora i samotná píseň byly doprovázeny projekcemi obrazů Smrtek (koster) vytvářejících spolu s jevištní akcí vertikální (intelektuální) montáž. Ta byla založena na konfrontaci různých podob a významů kostry: světské obrazy proti náboženským, lidové pojetí proti oficiálnímu. Oficiální kult reprezentovaly výjevy z tanců Smrti převzatých z barokních rytin, jako např: Smrt jako nevěsta a ženich (Obr. 2), Smrt vedoucí průvod vysokých představitelů světské a církevní moci (Obr. 3). Světský význam kostry se objevil na diapozitivu rytiny převzaté z Komenského učebnice Orbis Pictus, konkrétně z části kostra a maso, na níž je vysvětlena anatomie člověka (KOMENSKÝ 1941: 85) (Obr. 4). ${ }^{18}$

Lidové zpodobnění Smrti bylo zastoupeno zpěvaččinou maskou, ale i diapozitivem rytiny Smrti, již Honzl převzal z Novotného Špaličku (NOVOTNÝ 1940: 108) (Obr. 5), a dvojicí kreseb lidového pojetí tanců Smrti vytvořených Bohumilem Němcem: Smrt s dítětem a Smrt se šlechticem (PJH 023aI-PK) (Obr. 6).

Kontrastní pojetí Smrti u šlechty a u lidu bylo zdrojem dramatičnosti pásma. Ta nepramenila z konfliktu mezi postavami, ale $\mathrm{z}$ „napětí v řazení faktů, [ze] zjevn[é] srážk[y] různých názorů a různě koncipovaných vztahů ke skutečnosti“ (DVOŘÁK 1964: 218).

Dramatičnost a divadelnost samozrejmě souvisela i s Honzlovou prací s texty písní a ze zpo̊sobu jejich prezentace na scéně. Př́íkladná píseň o smrti člověka je lyrický

17 V roce 1935 přetiskuje Josef Vašica úryvky z barokních kancionálů a teoreticky se jimi zabývá ve své publikaci České literárni baroko.

18 Za zmínku stojí, že Komenského Orbis Pictus byl vydán nakladatelstvím Fr. Borový, které sídlilo v Topičově domě, ve stejném roce jako měly premiéru ČCK. 
Eva Šlaisová

Od smutného Pierota k pyšnému vezírovi aneb Honzlovy České písně kramářské

틀

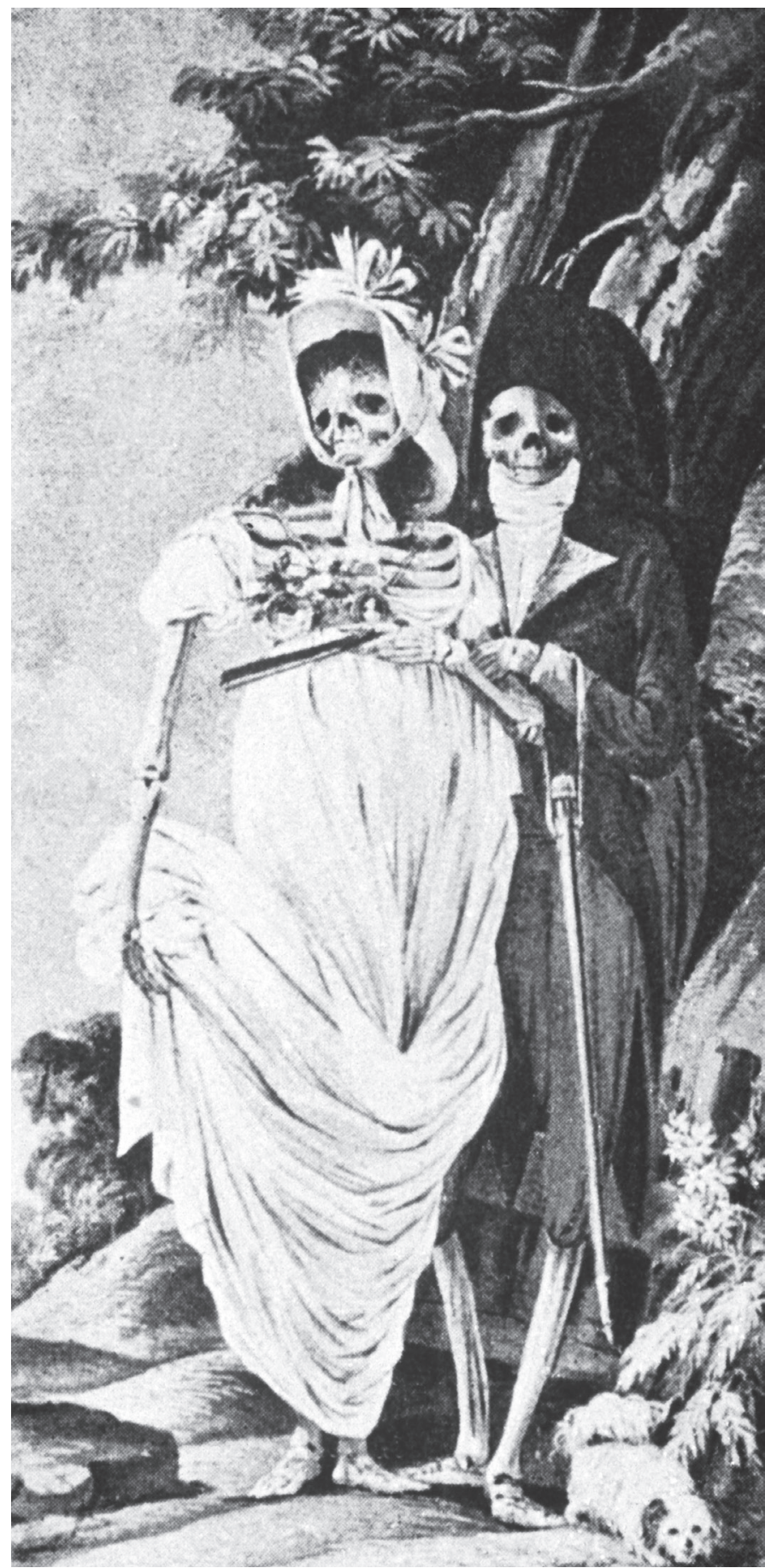

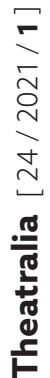

Obr. 2: Tanec Smrti I (dp. č. 3, PJH) 


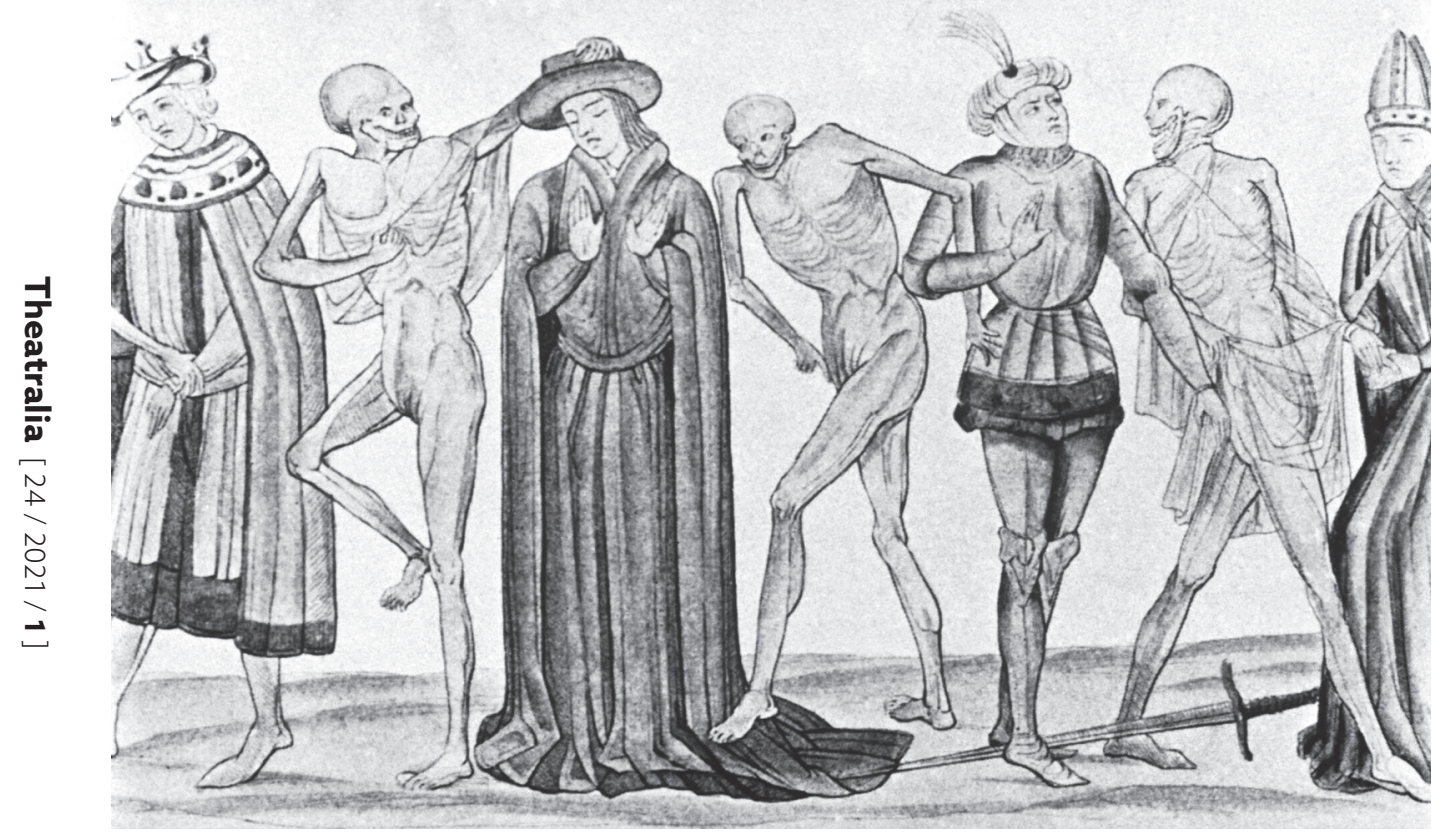

Obr. 3: Tanec Smrti II (dp. č. 7, PJH)

monolog Smrti demonstrující svou moc nad životem všech společenských vrstev. Ústředním dramatizačním prvkem originální písně je její vztažení k aktuální situaci prostřednictvím dvou různých subjektů - posluchačů a zpěváka, ${ }^{19}$ kterým je píseň adresována. Jejich stř́́dáním vzniká pocit dialogičnosti a na rozhraní strof, v nichž se objevují jiní adresáti, dochází k významovým zvratům typickým pro dialog (přestože je mluvčí týž) (VELTRUSKÝ 1994: 72). Proměny adresátů promluvy jsou zdrojem napětí, jež souvisí s rozšiřováním moci Smrti.

Honzl tento dramatický aspekt písně zesílil jednak tím, že přidal adresáta třetího komentátora, jednak tím, že sloky, v nichž se Smrt obrací na zpěvačku a na komentátora umístil na závěr. Vrcholem písně tak učinil strofy nejvíce dramatické, v nichž Smrt o své moci pouze nevypravovala, ale již „tady“ a „ted"“ manifestovala.

Originální byl i způsob, jakým Honzl píseň inscenoval. Pokud by byla tato píseň předváděna podle pravidel jarmareční písně: zpěvák by zpíval part smrti, smrt a její moc by byly ukazovány na obrazové tabuli. Zpěvák by byl nositelem jejích auditivních znaků, tabule vizuálních. Honzl upustil od tohoto stereotypního podání a rozdvojený subjekt Smrti sjednotil v jedné herecké postavě. Postava Smrti „splynula“ se zpěvákem, resp. Smrt byla zpěvákem. Nicméně toto sjednocení bylo po celou dobu výstupu

19 Smrt se obrací na posluchače nikoli konvenčním „poslyšte křestané“ nebo „poslyšte mládenci a panny“ apod., ale rozkazem: „stůj, na rozkaz mé jasnosti, pokloň se velebnosti“. Tento způsob, kdy není navázán kontakt s publikem prostřednictvím uvozovacích - stereotypních - formulí, ale bezprostředním vtažením do děje či úvodní úvahou, považuje Bohuslav Beneš za typický znak dramatických kramářských písní (BENEŠ 1971: 105). 


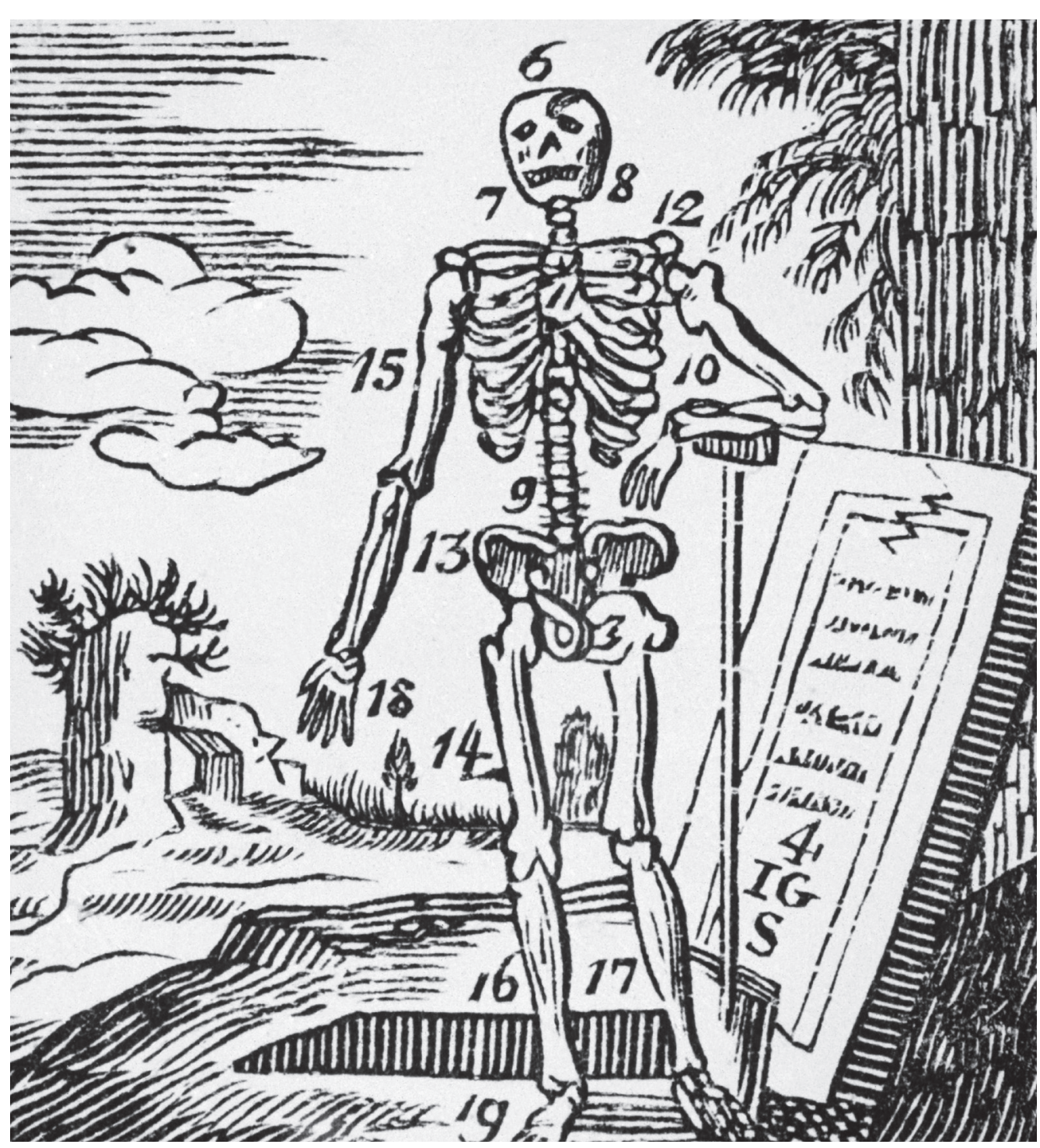

Obr. 4: Komenského anatomie člověka (dp. č. 4, PJH)

rozrušováno projekcemi, které obraz Smrti na scéně pluralizovaly, naznačovaly možné rozdvojení.

Některé části písně Smrt zpívala, jiné recitovala. Pohybovala se po jevišti směrem k divákům a od nich, při slokách, kdy zpívala o tom, koho všeho přemůže, kosila kosou. $\mathrm{Z}$ inscenačního hlediska byl nejpůsobivější závěr písně (předposlední sloka), kdy se Smrt obrací na zpěváka: 


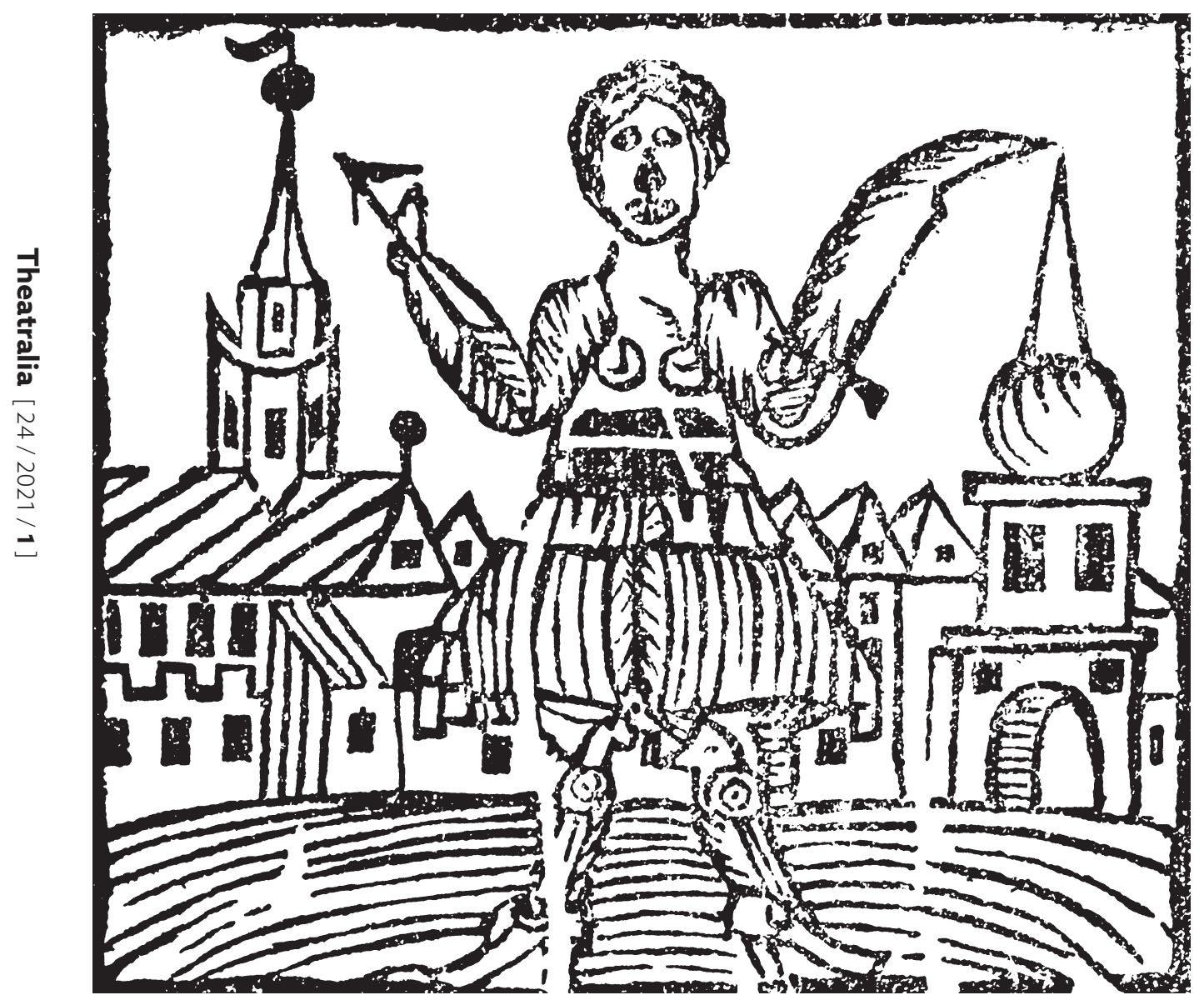

Obr. 5: Rytina Smrti z kramářského tisku (dp. č. 6, PJH)

(světlo na zpě̀vačku)

Ty, který tu zpíváš nyní (sejme masku)

s tvojima posluchači (masku $k$ posluchačim)

měj se na dobrém pozoru, (masku $k$ sobě $)$

má ruka tě zatlačí.

Snad ještě dnes aneb zejtra (pomalu masku před obličej)

pustím svůj meč na tebe,

nevím, kterou cestou půjdeš

do pekla neb do nebe. (odcházi držic masku vpravo)

(PJH 23/023a-IIb: 5)

Tato sloka (ve Smetanově - Václavkově antologii) zaujala Veltruského v souvislosti se způsobem, jakým bylo využito rozdělení znaku postavy (Smrti) mezi obraz a zpěváka. Nejedná se totiž o konvenční způsob, kdy zpěvák hovoří „za“ Smrt, ale sám se stává adresátem její promluvy: „Smrt oslovuje zpěváka, ovšem ústy právě toho zpěváka“ 


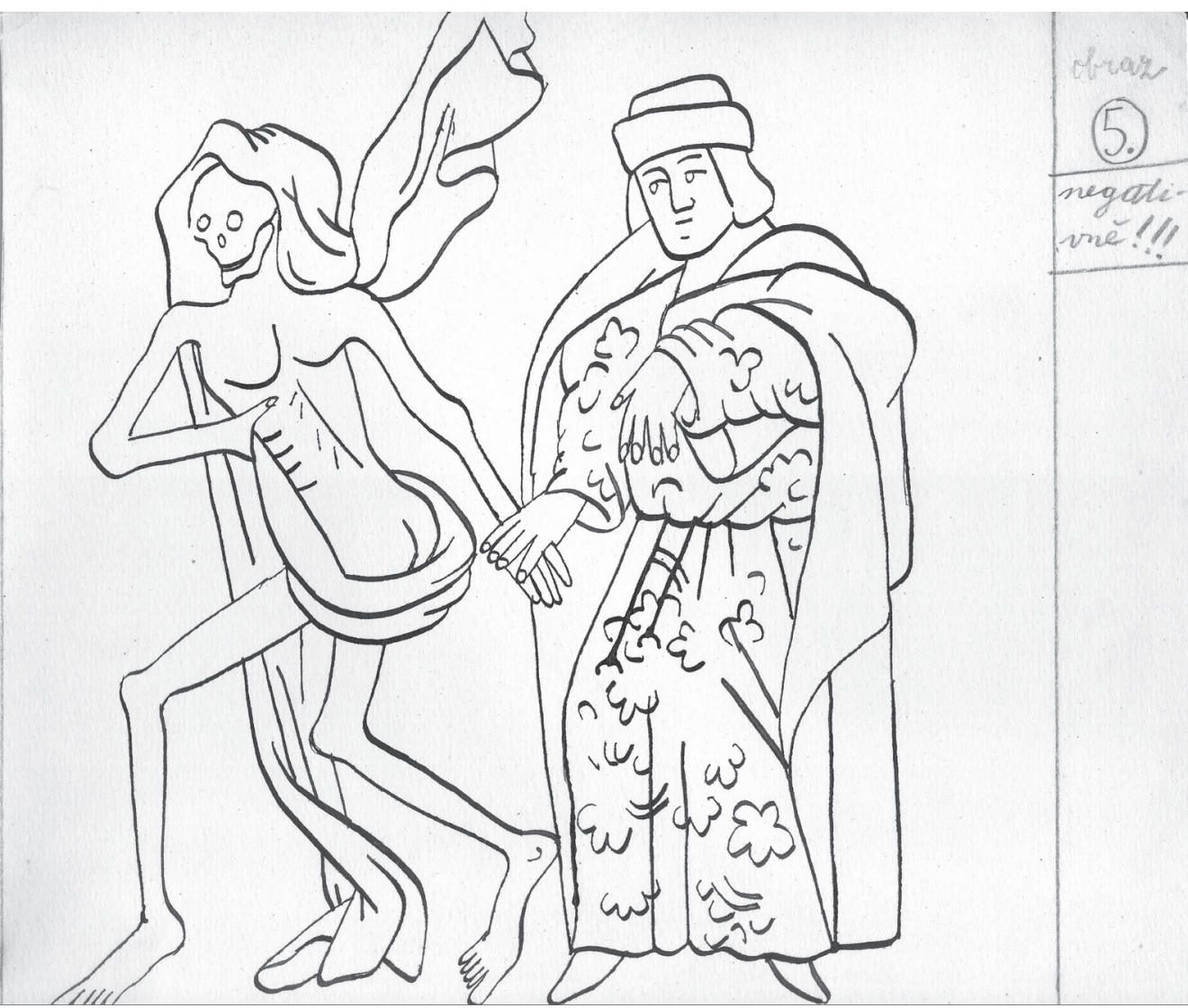

Obr. 6: Bohumil Němec, Tanec Smrti

(dp. č. 5; originál kresby PJH 023al-PK, @ BohumilNěmec - OOA-S, 2021)

(VELTRUSKÝ 1994: 70). Honzl dosahuje stejného efektu tím, že si zpěvačka sejme masku, která k ní promlouvá. ${ }^{20}$

Druhou písní byla „Novina velmi žalostná, která se stala s jednou paní, páchajíce ona cizoložství [...]“, která formou náboženského exempla upozorňovala na to, jaká pekelná muka čekají hříšníky - cizoložníky.

I komentář k této písni Honzl vystavěl na protikladu, konkrétně na odlišném chápání nevěry u šlechty a u lidu. Zatímco pro lid, podle Honzla, představovala nevěra hřích, pro šlechtice zábavu či módu (PJH 23/023a-IIb: 21).

20 Veltruského studie, která patří mezi první pokusy o popis poetiky kramářské písně z pohledu dramatu a divadla, vyšla ve stejném roce jako měly premiéru Honzlovy $\check{C} P K$. Oba si pro své teoretické / umělecké dílo vybírají i stejné písně („Lamentací tureckého vezíra“ a „Př́kladnou píseň o smrti“). Ať už se jedná o náhodu, inspiraci z jedné či druhé strany či dvojí produkt společných rozhovorů, je zřejmé, že Honzl realizoval na jevišti, co Veltruský teoretizoval. Honzlova montáž kramářských písní spočívala na principech popsaných Veltruským: hře se subjektem mluvčího a adresáta a možnostmi zapojení obrazové tabule do inscenace, jež souvisí s rozdvojováním a multiplikací divadelních znaků. 


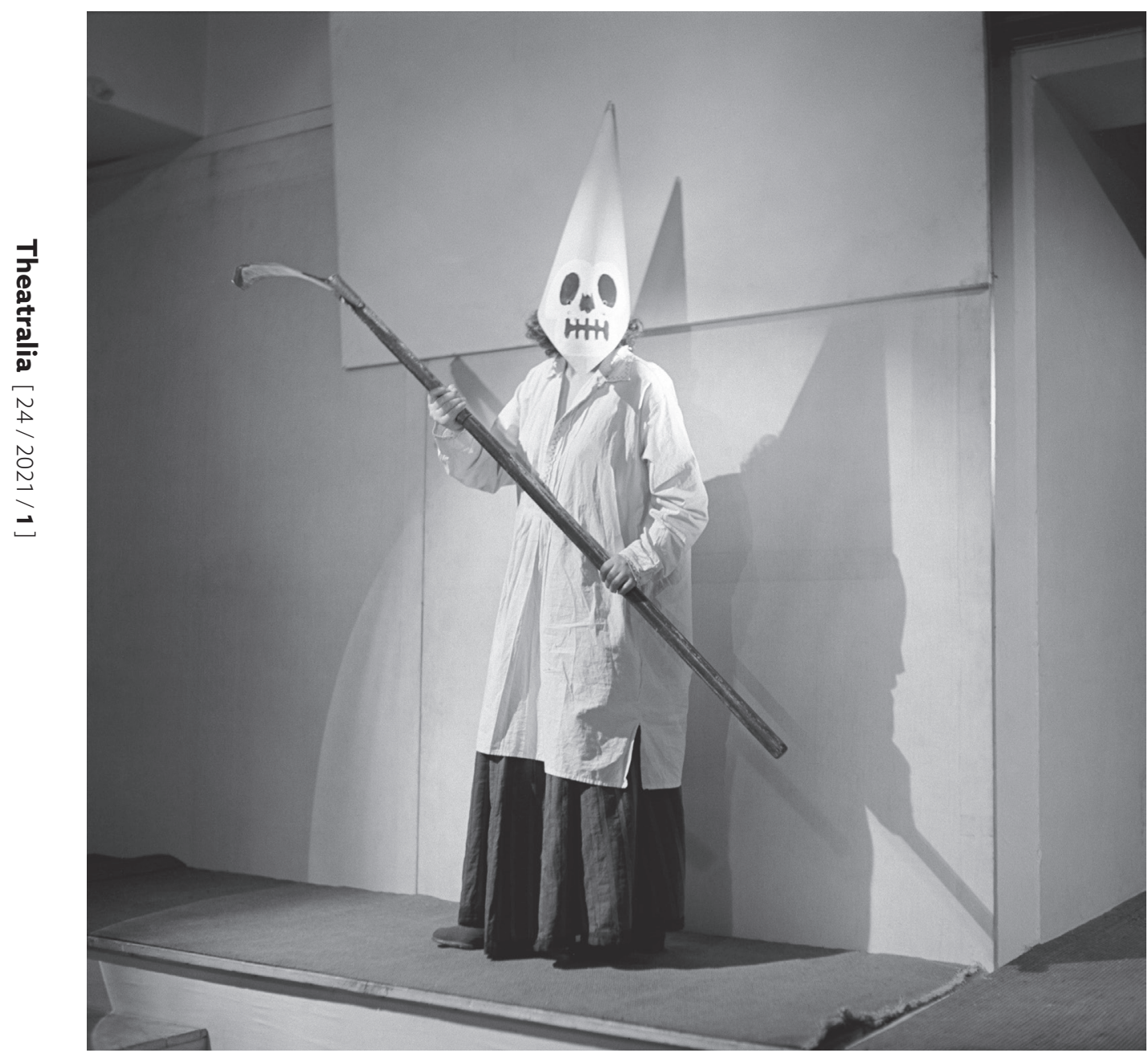

Obr. 7: Postava Smrti (Alexandr Paul, Archiv atelieru Paul)

Protiklad byl manifestován projekcemi diapozitivů, na nichž byla, slovy Honzla, konfrontována „rokoková pornografie“ s lidovými dřevoryty či Němcovými kresbami (PJH 23/023a-IIb: 23). Pod výrazem „rokoková pornografie“ se skrývaly obrazy Jeana-Antoina Watteau zachycující dvorskou lásku a mravy. Honzl např. použil Watteauovy obrazy Toaleta (diapozitiv č. 9), Překvapeni (diapozitiv č. 10) ${ }^{21}$ a Chybný krok (diapozitiv č. 12). ${ }^{22}$

21 Obraz Překvapeni byl pravděpodobně promítán dvakrát. Jednou celý, tj. výjev s milenci a Mezzetinem hrajícím na kytaru, podruhé pouze zvětšený detail postavy Mezzetina (diapozitiv č. 11).

22 Výběr obrazů nereflektuje pouze svět rokokové společnosti a poetiku jejího umění, ale také rezonuje s dobovým uměním, konkrétně se surrealismem a jeho zájmem o erotično a libertinské období rokoka. V ČPK Honzl vztah rokoka a surrealismu netematizuje, jako to např. činil ve Večeru s Vítězslavem Nezvalem; surrealismus pouze tvoří dobový referenční rámec. 


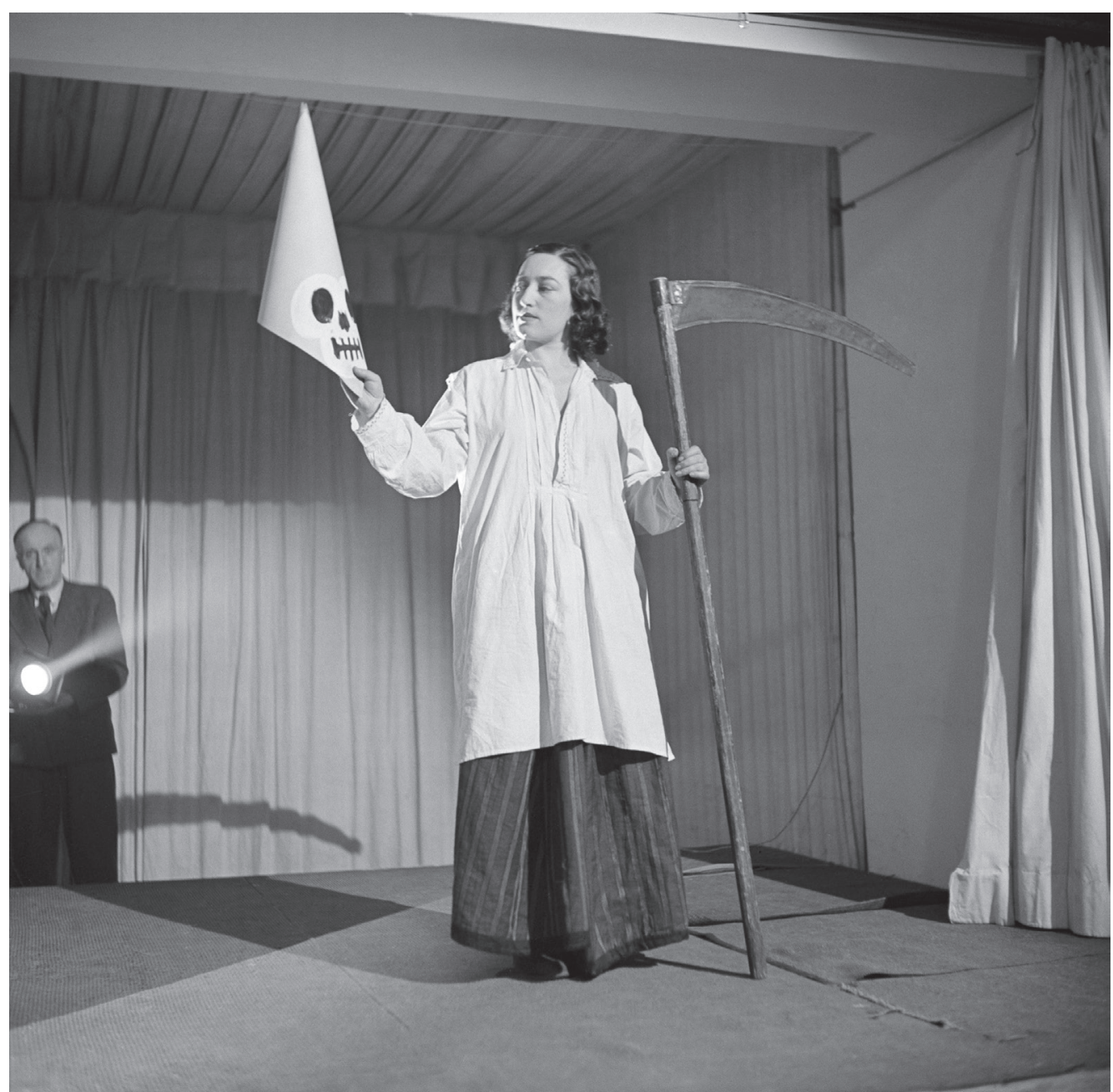

Obr. 8: Postava Smrti (Alexandr Paul, Archiv atelieru Paul)

Dichotomii ve vnímání nevěry demonstroval Honzl i na slovesném materiálu. Na straně vysokého umění stály výňatky ze hry Williama Congreva, Tak to na tom světě chodí (1700), které Honzl začlenil do komentátorova výkladu, na straně druhé text kramářské písně podávající zprávu o tom, co se stalo s cizoložnicí. Píseň byla vyprávěna (zpívána) zpěvákem (Z. Stránský) a zpěvačkou (M. Wildová). Zpěváci se střídali ve funkci vypravěče tam, kde se vyprávělo o minulé události; větší část textu náležela Stránskému. Zpěvačka nadto popisovala smrtelná „pekelná“ muka cizoložnice, jež byla vyobrazena na světelných obrazech (Obr. 11, 12, 13). 


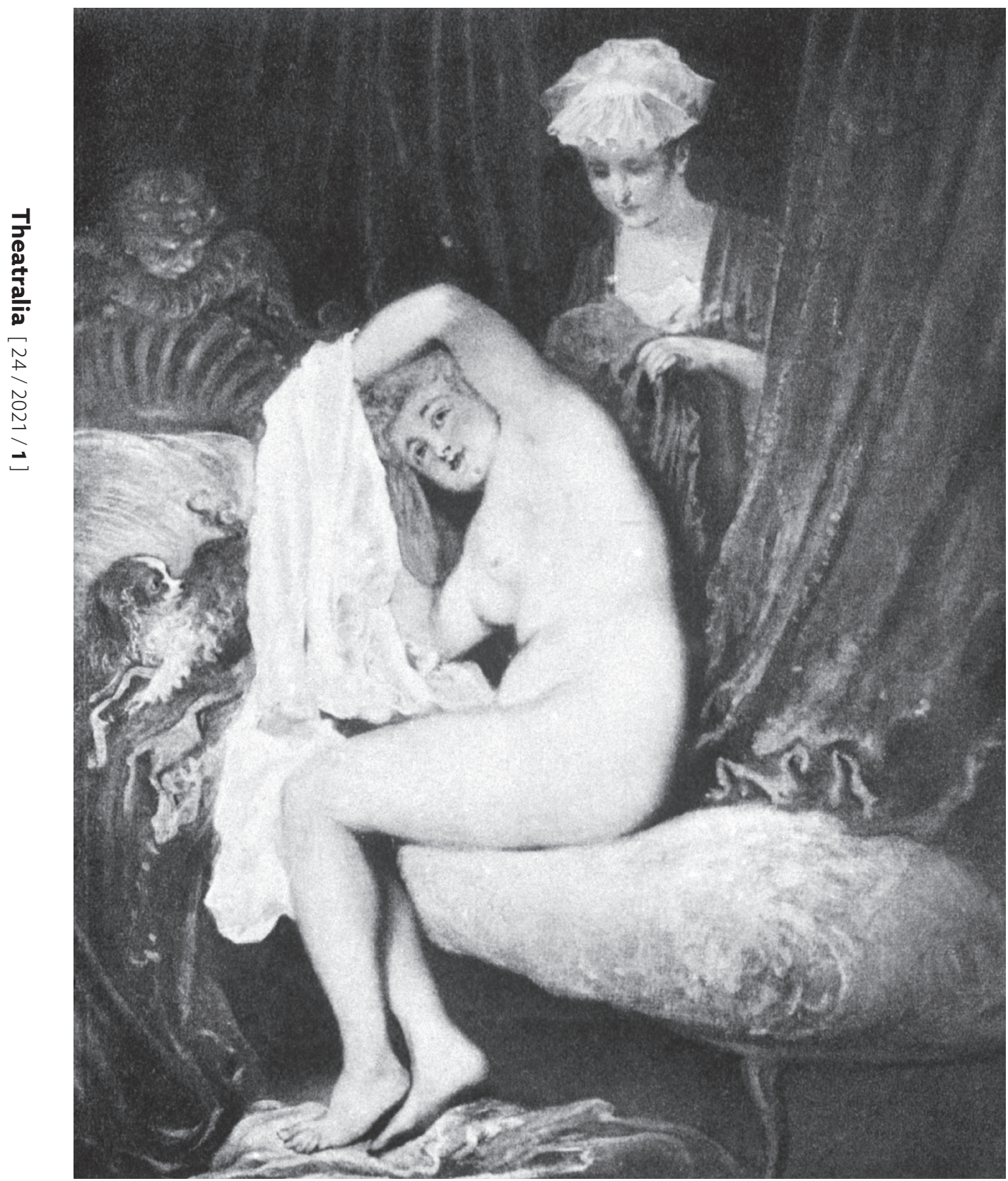

Obr. 9: Jean Watteau, Toaleta (dp. č. 9, PJH) 
Eva Šlaisová

Od smutného Pierota k pyšnému vezírovi aneb Honzlovy České písně kramářské

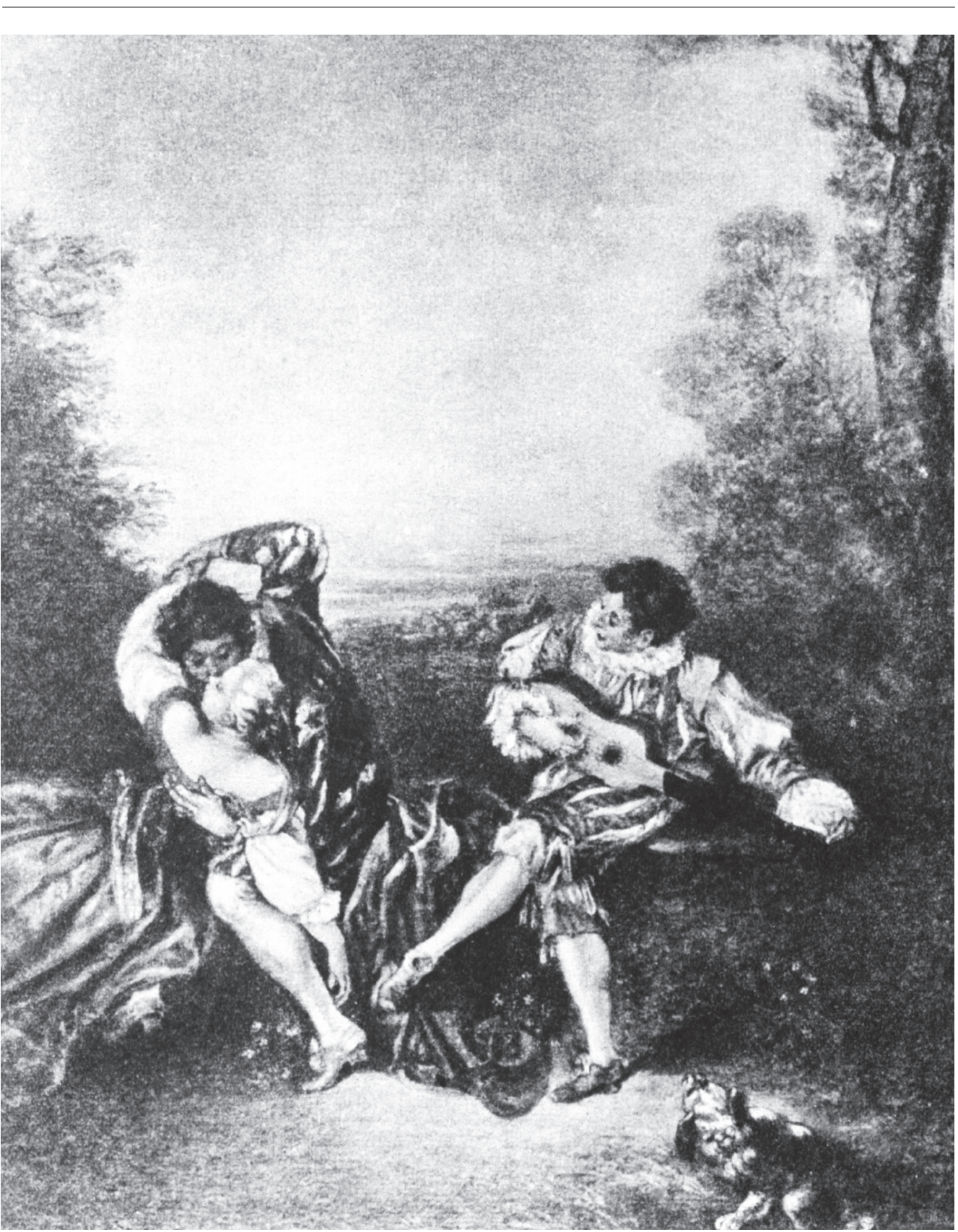

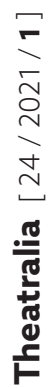

Obr. 10: Jean Watteau, Překvapení (dp. č. 10 PJH) 


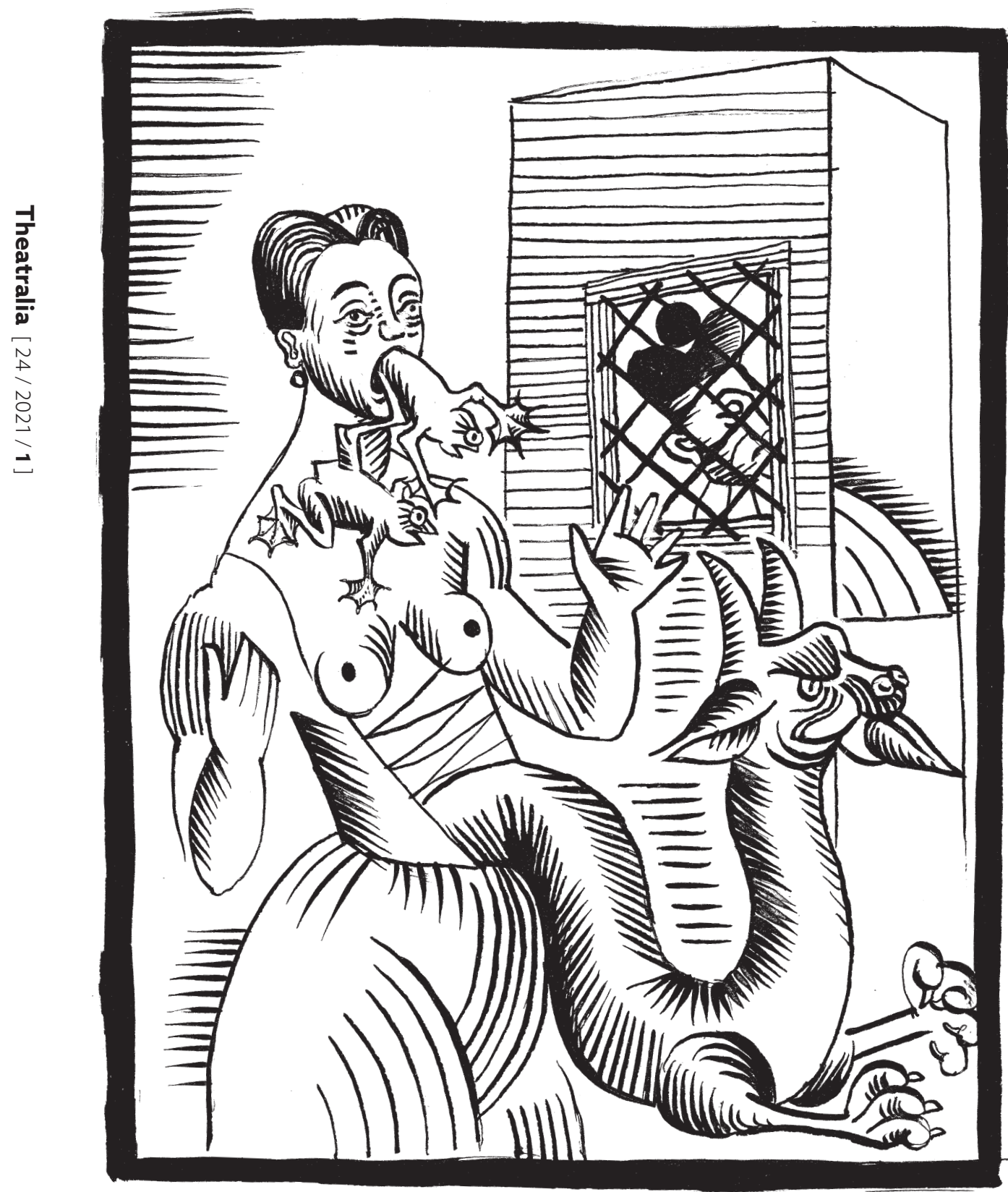

Obr. 11: Bohumil Němec, kresba pekelných muk (PJH 023al-PK, @ BohumilNěmec - OOA-S, 2021) 


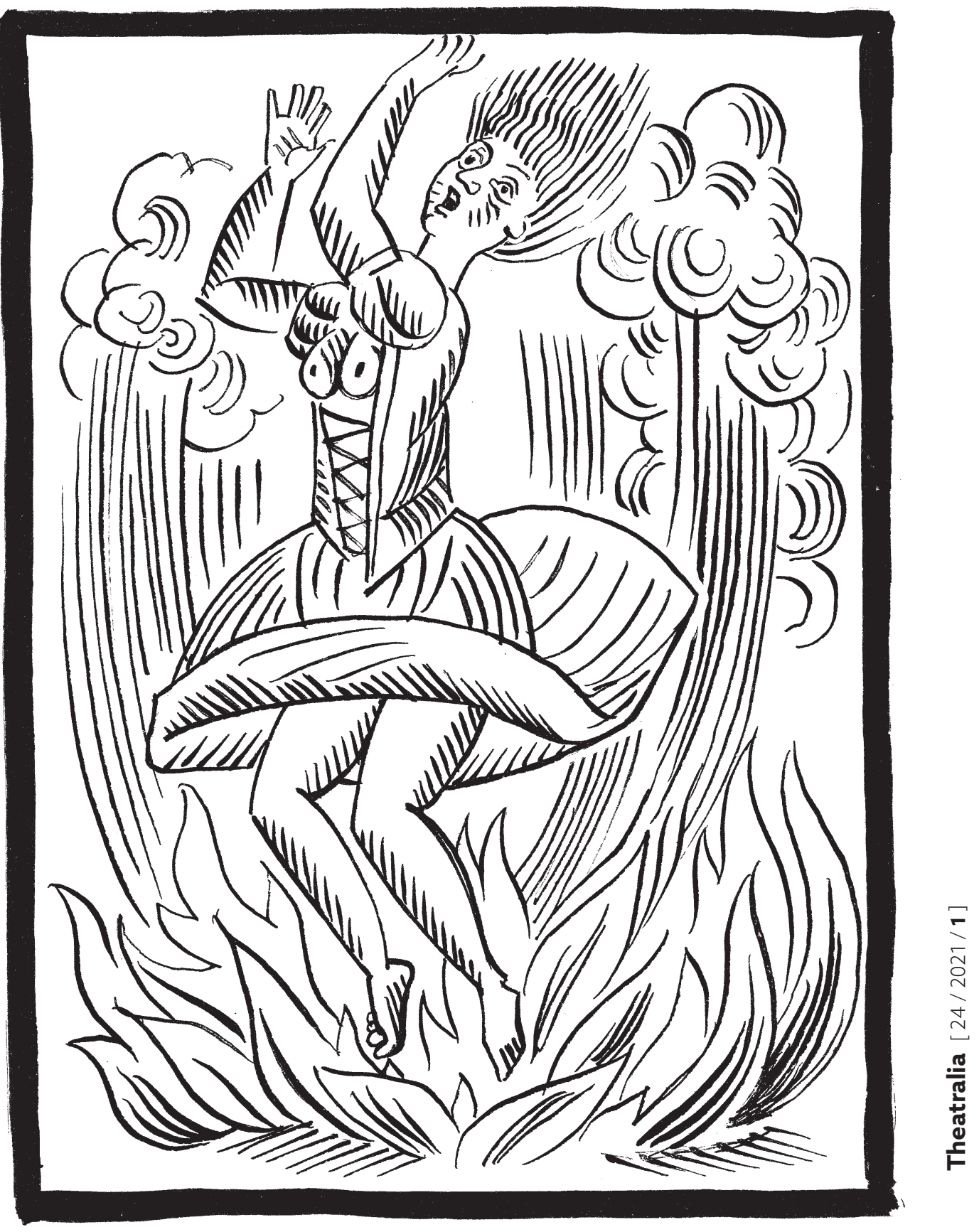

Obr. 12: Bohumil Němec, kresba pekelných muk (PJH 023al-PK, (c) BohumilNěmec - OOA-S, 2021) 


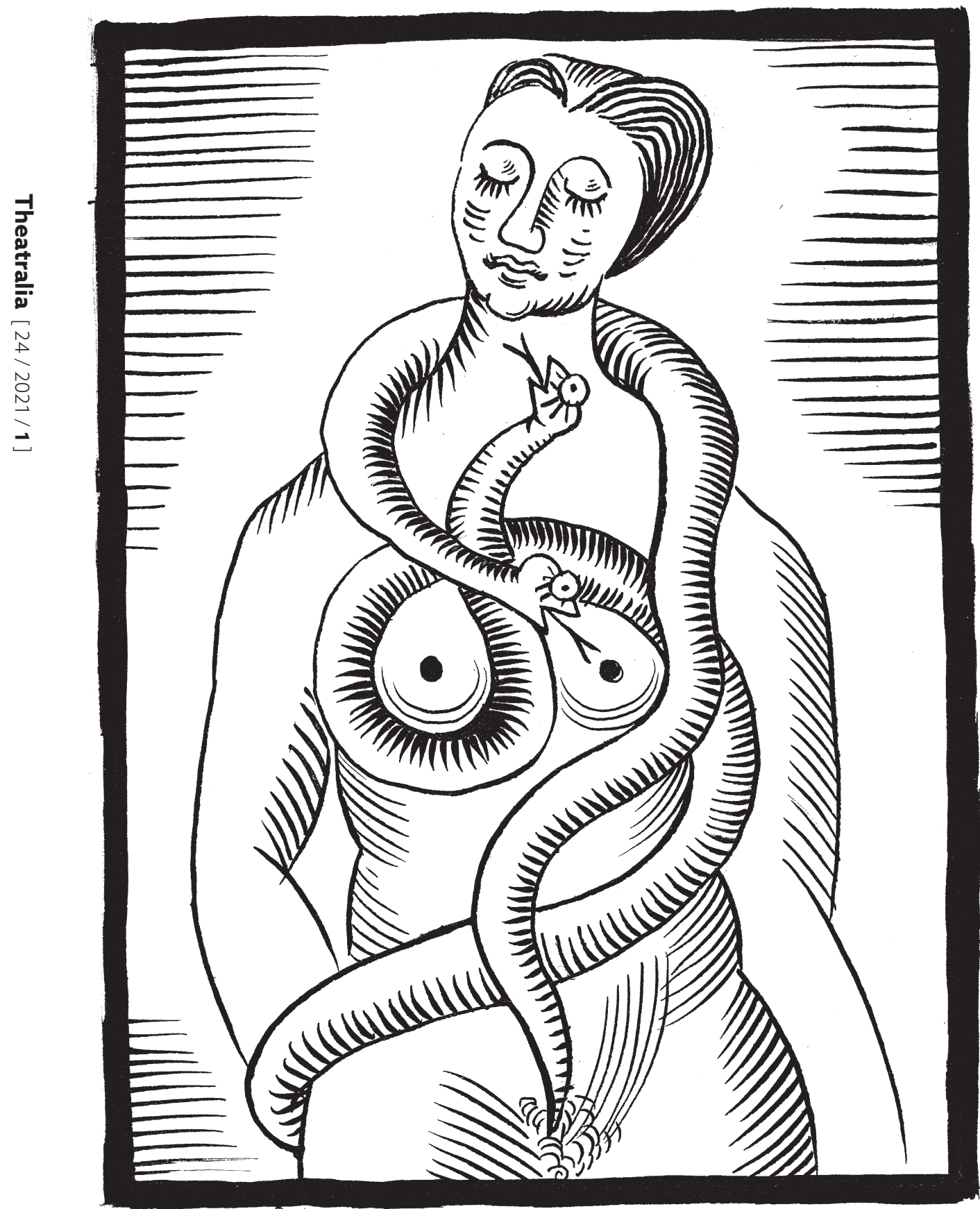

Obr. 13: Bohumil Němec, kresba pekelných muk (PJH 023al-PK, (c) BohumilNěmec - OOA-S, 2021) 
Třetí píseň pásma, „Píseň ke cti a chvále blahoslavené Panny Marie častochovské [...]“ z roku 1790, přinášela téma zbožnosti, lásky k Panně Marii. I zde se Honzl pokoušel konfrontovat strohost oficiálního kultu, dovolujícího „milovat pouze Krista a [...] Pannu Marii“ (HONZL 1964b: 90), a př́ivětivost kultu lidového, při jehož uctívání je možné/ snadné, podle Honzlova názoru, zaměnit lásku náboženskou za lásku světskou. ${ }^{23}$

Píseň byla inscenována jako procesí, což vycházelo z první sloky, kdy zpěvák oslovuje pomyslného poutníka a zve ho na pout do Častochova „za [svou] milou Pannou Marii“ (PJH 23/023a-IIb: 28). Píseň byla střídavě zpívána a recitována zpěvákem - předř́íávačem v čele procesí, jímž nebyl kněz, ale vesnický mladík (VYSKOČIL 1961: 170) - a sborem tř́i žen (PJH 23/023a-IIb: 28).

Po formální stránce píseň představuje milostný lyrický monolog adresovaný Panně Marii, která je v duchu barokní mystické erotiky pojímána jako milenka. Právě tento kontrast mezi duchovním a světským, zbožným a smyslným, je zdrojem významových zvratů. Obdobně jako v první písni jsou dosaženy proměnami adresáta, nejedná se však o rozšiřování počtu adresátů, ale o stř́ídání, splývání a rozdělování adresátů dvou: milenky duchovní a světské. Tuto podvojnost obsaženou v původní písni Honzl rozvedl a zdůraznil.

Např́íklad při druhé sloce, kdy je oslovována Panna Maria (jako milenka, holubička a perlička), byly na scéně promítány dva obrázky na skle s motivem Panny Marie, převzaté z knihy Naděždy Melníkové-Papouškové. ${ }^{24} \mathrm{~V}$ páté sloce, kdy Honzl změnil oslovení z „ó Maria“ na „děvče jasné“, byl na scéně promítnut „obraz děvčete“ (PJH 23/023a-IIb: 29). Ten byl vytvořen úpravou (fotomontáží) jednoho z předchozích obrazů svaté, která byla podle Honzlových poznámek „zbavena Ježíška, koruny [a] svatozáře" (PJH 23/023a-IIb: 29) (Obr. 14, 15, 16). Tyto dva odlišné adresáty promluvy sloučil v předposlední sloce písně. Při její recitaci požadoval, aby byl „obraz Marie a dívky zkombinov[án]“ (PJH 23/023a-IIb: 29).

Mezi projekcí obrazů světic a dívky byl promítnut ještě lidový dřevoryt srdce řezaného pilou a probodnutého šípem (diapozitiv č. 22a, převzatý z Novotného Špalícku). I tento symbol osciluje mezi duchovním a světským významem charakteristickým pro píseň. Na jedné straně se váže k religióznímu symbolu srdce (Ježǐše, Panny Marie) vyjadřujícímu lásku/utrpení, na druhé straně se váže $\mathrm{k}$ milostnému utrpení vyjádřenému v jazykové podobě v lidové písni z Erbenovy sbírky: „když se loučí milej s milou/ řezají si srdce pilou“ (ERBEN 1864: 403)..$^{25}$ Tento diapozitiv nedodával „celému výstupu [pouze] zvláštní atmosféru“, jak se dočítáme u Vyskočila (1961: 170), ale vyjadřoval základní dualitu písně jiným způsobem - symbolem.

23 „[...] svatý obrázek laskavé Panny nahrazoval milostné touze všechny panny jejichž krása kdy rozbušila mládencovo srdce. Obrázek nejsvětější Marie ukryl ochotně všechny výzvy, jež slibovaly jinochům nejsladší hřích“ (HONZL 1964b: 90).

24 O svaté na diapozitivu č. 21 hovoří Honzl v režijní knize jako o Panně Marii (PJH 23/023a-IIb: 28), nicméně se jedná o detail obrázku svaté Rosalie (Podkrkonoší, polovina 19. století). Diapozitiv 22a zobrazuje Marii s Ježíškem (Slovensko, polovina 19. století) (MELNIKOVÁ-PAPOUŠKOVÁ 1938: obr. číslo 49 a 58). 


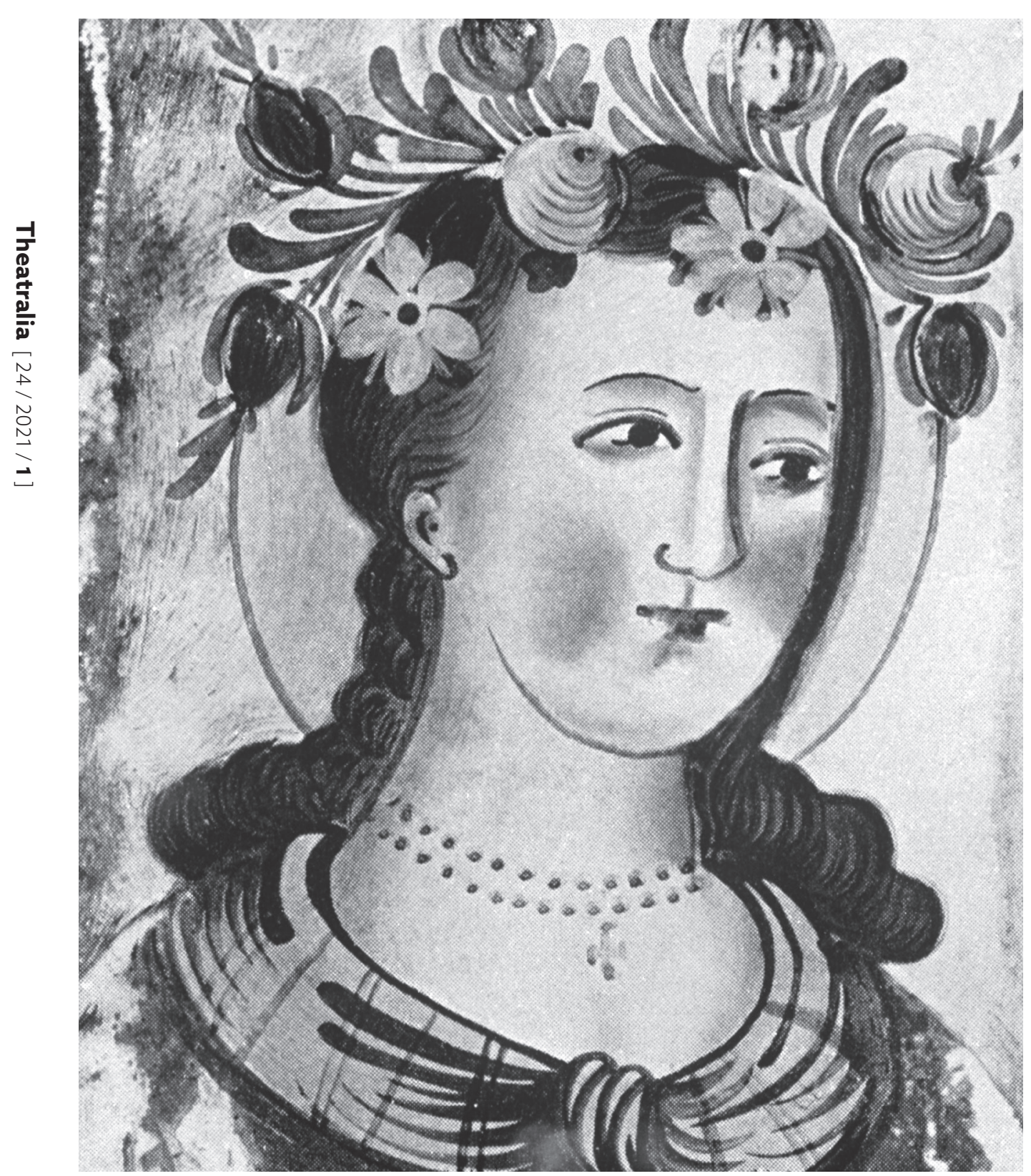

Obr. 14: Lidový obrázek na skle, „Panna Maria” (dp. č. 21, PJH) 


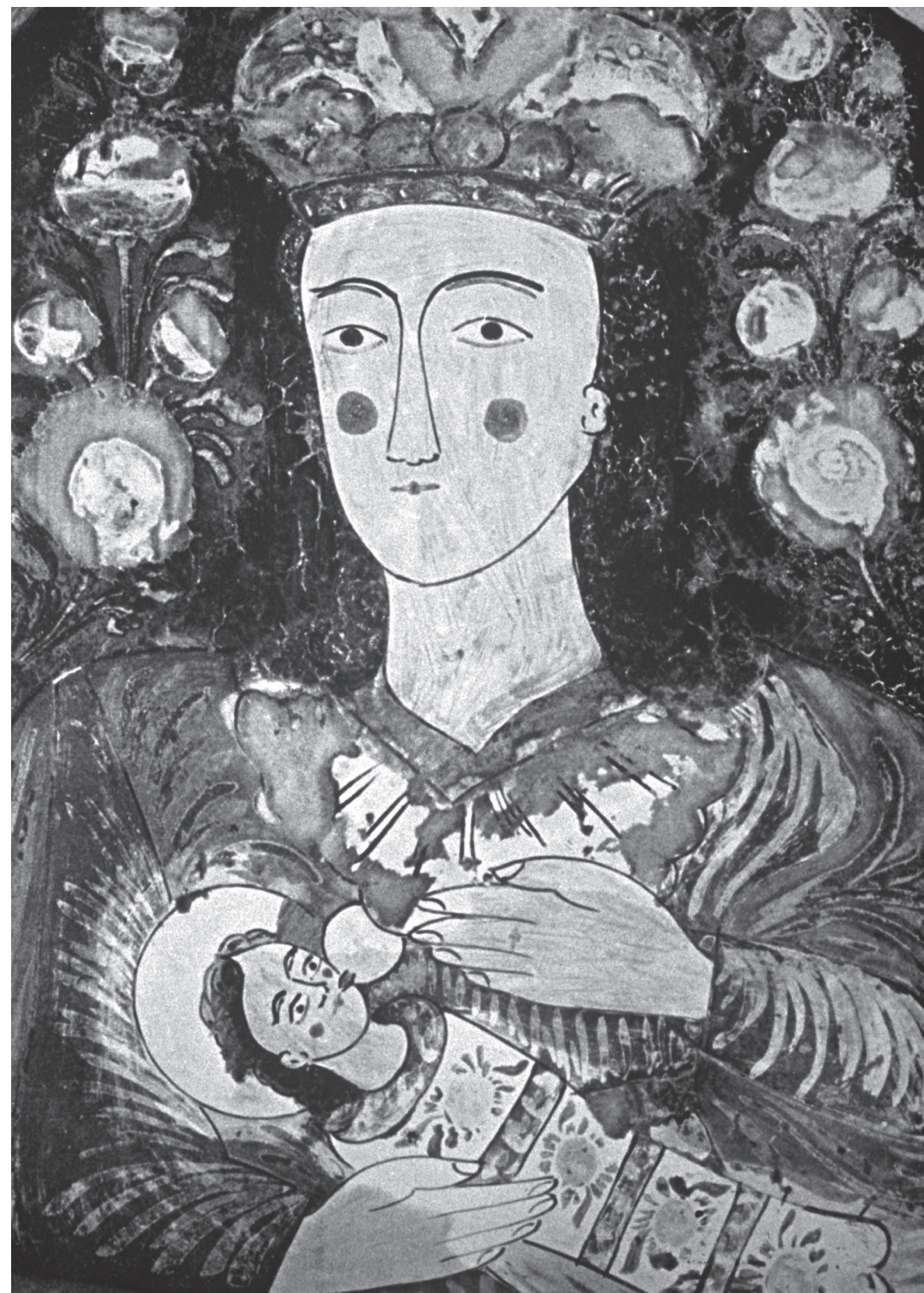

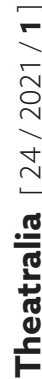

Obr. 15: Lidový obrázek na skle, „Panna Maria” (dp. č. 22, PJH) 


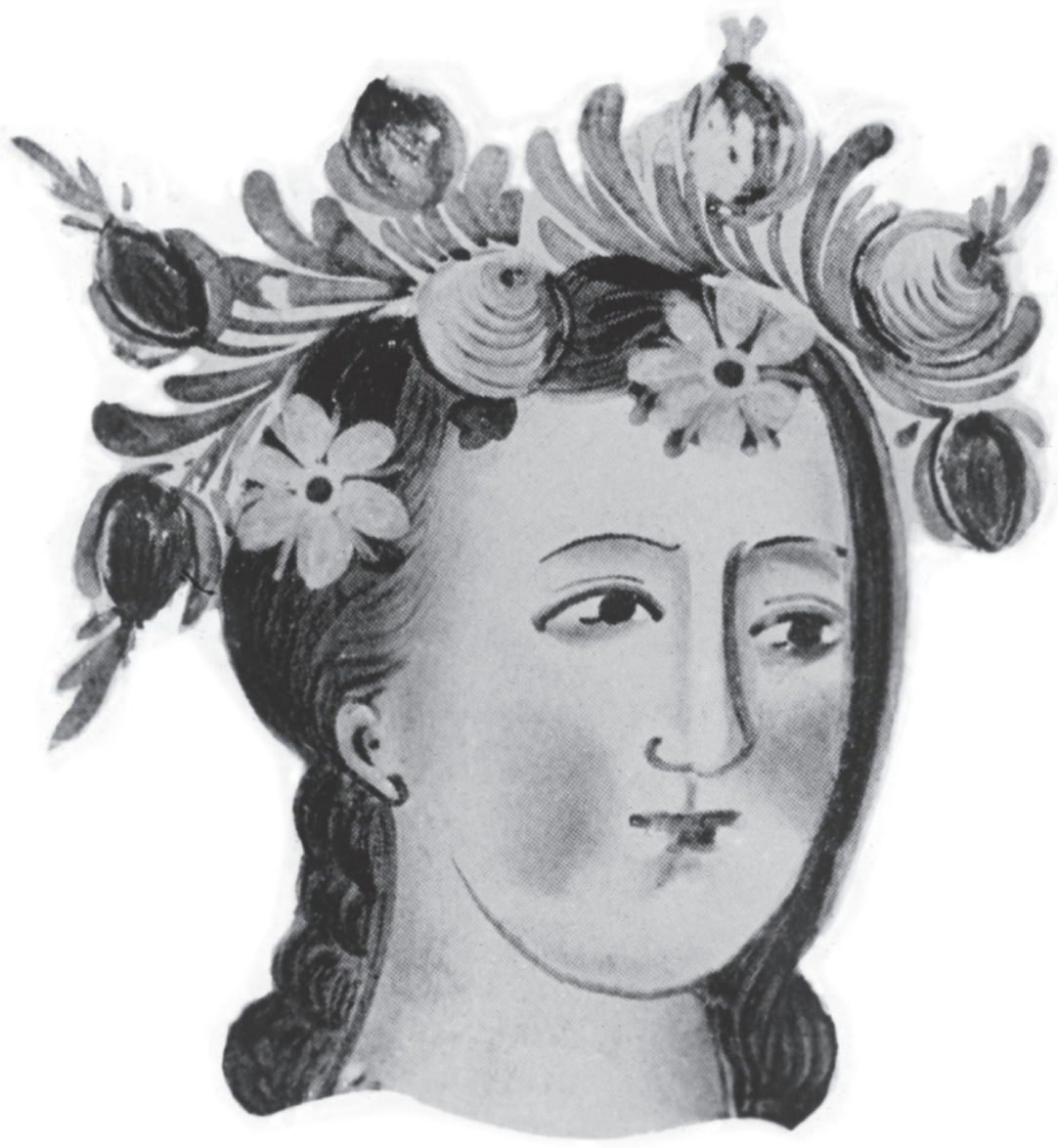

Obr. 16: Lidový obrázek na skle, dívka (dp. č. 23, PJH)

Píseň o Panně Marii uzavírala celek duchovních písní pásma a zároveň - prostřednictvím lidové verze barokního erotického mysticismu - tvořila přechod k následujícím dvěma písním první části programu, jejichž tématem byla láska světská. Také oddělovala sekci písní, jejichž dramatičnost spočívala velkou měrou v konfrontaci slovesné a výtvarné složky (projekcí), od písní, jež projekcí nevyužívaly. K projekcím se Honzl vrátil ještě v písni o povodni („Truchlivá novina o letošním pamětihodném povodni“) v druhé půlce programu, během níž bylo promítnuto přibližně třináct diapozitivů kreseb povodně Prahy v roce 1784 převzatých z kramářských tisků, dobových periodik apod. ${ }^{26}$ Zbylé čtyři písně („Píseň všem bohatým rodičům“, „Nová píseň na příklad mládencům

26 Podle recenze Nejedlého př̀i promítání diapozitivů v této písni došlo k poruše, která snížila celkový dojem z výstupu (NEJEDLÝ 1941). 
a pannám“, „Píseň kratochvilná o těch sedlácích“ a „Lamentace tureckého velkého vezíra“) byly založeny na souhře čtyř a více herců a byly inscenovány v duchu lidového divadla. Posun od písně k divadlu Honzl později zdůraznil i změnou názvi̊; v programu Studia ND nejsou tyto výstupy uvedeny jako písně, ale jako hry („Hra o tom, co se stalo v městě Jilemnici“, „Hra o Karolíně“, „Hra kratochvilná o těch sedlácích“ a „Hra o prohrané bitvě“"). ${ }^{27}$

\section{Světská láska tragická}

Světské písně otvírala „Píseň všem bohatým rodičům“, jež představuje variantu příběhu, který v Čechách proslavil Karel Jaromír Erben ve své „Svatební košili“. Jednalo se o jednu z nejdramatičtějších písní pásma, co se týče organizace jazykového materiálu, nebot příběh byl rozvíjen ve velké míře prostřednictvím dialogů. $\mathrm{V}$ písni vystupovali kromě vypravěče (zpěváka) čtyři postavy - matka, dcera, syn řemenáře Vilhelm a umrlec. Postavy byly zpodobněny čtyřmi loutkami, jež mohly pohybovat hlavou a rukama a jejichž stín byl promítán na projekční plátno. Za ním byli schováni čtyři herci, kteří za loutky promlouvali (VYSKOČIL 1961: 170). Plátno, resp. stínohra, nahrazovalo obrazovou tabuli. Tato spojitost byla naznačena postavou zpěvačky, která „přišla na scénu s židlí, sundala si šátek, do vlasů si dala růži, začala zpívat a ukazovat hůlkou na projekční plátno,“ na němž nebyly jednotlivé výjevy z písně namalovány, ale živě odehrány (PJH 23/023a-IIb: 32):

např: ZPĚVAČKA (zpívat): Matka vyšla ven, na ni volala, aby šla domů a se modlila.

DÍVKA (mluví): Darmo modlení, darmo trápení, dívka když já se soužím pro potěšení.

Pro potěšení.

ZPĚVAČKA (zazpívat): Když krásné hvězdy svítit počaly, ona slyšela dupot od koní.

(pauza)

DÍVKA (mluví): Ach Bože, Bože! Kdo to k nám jede? Dívka mluvi obracejíc hlavu

Otvírají se vrata oboje.

Vrata oboje.

HOCH (mluví): Jedu, má milá, jedu pro tebe, kostlivcova ruka

protože nemám v hrobě pokoje.

Vstávej, má milá, vstaň z lůže svého, musíš opustit manžela svého.

Manžela svého.

DÍVKA (mluví): I já žádného manžela nemám, dívka mluví na tebe, Vilhelm, na tebe čekám! 
HOCH (mluví) ${ }^{28}$ : Vstávej, má milá, vstaň se šňůrovat, čas mně uchází, nemohu čekat.

Nemohu čekat.

Můj kůň je rychlý jak střelná rána, co mně ujede sto mil do rána: kostlivcova hlava a když přijedem z města za bránu, hosti čekají na naši svatbu.

Na naši svatbu. (TMA)

ZPĚVAČKA (zpívá): A když přijeli z města za bránu, hosti čekali na jejich svatbu: (SVĚTLO)

HOCH (mluví): otvírejte se vrata kerchovní, kostlivcova hlava vezu nevěstu, to Vilhelmoví.

To Vilhelmoví.

ZPĚVAČKA: Žalostně praví, zase po druhé:

HOCH: Otvírejte se, dveře hrobové!

ZPĚVAČKA: Dveře hrobové se otevřely,

Vilhelm s Anežkou oba tam vjeli. (TMA) dívka a smrt

(PJH 23/023a-IIb: 33)

Na levém okraji režijní knihy Honzl poznamenával převážně instrukce pro herce, na pravé straně jsou většinou zaznamenány informace týkající se zapojení loutek. Přepis vydává mnoho detailů o zpơsobu inscenování písně. Zpěvačka zde měla roli extradiegetického vypravěče; markantní je tento posun mezi vyprávěním (z venku) a předváděním akce/děje ve stejných replikách, které jsou jednou součástí zpěvaččina partu ve formě epického préterita a vzápětí se objevují v replice chlapce jako dramatický prézens. Zpěvaččin odstup od zobrazovaného děje byl umocněn nejen jejím umístěním před projekčním plátnem, jiným gramatickým časem (vyprávěním o minulé události), ale i zpěvem, nebot’ repliky jednotlivých postav byly herci pronášeny. Vypravěčka zpívala - vyprávěla - o někom jiném jako o třetích osobách a nepřeměňovala se v ně. Postavy (stínové loutky) příběh, resp. vybrané motivy př́iběhu, zpřítomňovaly - předváděly.

Po této písni následovala „Nová píseň na příklad mládencům a pannám“ o vraždě krásné Karolíny, jež je ve své původní podobě kromě dvou přímých řečí celá vyprávěna. Honzl píseň nechal beze změny, pouze její jednotlivé části rozdělil mezi tři vypravěče. Každý z nich ztvárnil jinou postavu, příp. postav několik: Pehr - Pepíček, Máchová/ Berková - Karolína, Wildová byla pouze vypravěčem.

28 Od tohoto místa Honzl slovně neuvádí, jaká postava hovoří/zpívá, nicméně party dívky a hocha podtrhává, prríp. ještě označuje svislou čárou po straně veršů/slok. Výstupy zpěvačky nechává bez označení. Variantu této písně Honzl začlenil do své montáže Lidové balady, v níž mělo být stínové divadlo nahrazeno projekcemi. 
Jedna, dva, tři, čtyři $(\mathrm{M})$, pět $(\mathrm{P})$, šest $(\mathrm{W}),{ }^{29}$

sedum, vosum, devět, deset,

Vš [všichni]: jedenáctá hodina, (otáčet hlavou)

W: ta Pepíčka zbloudila.

K [Karolína]: Zbloudila ho velmi prudce, (zkř́ízit ruce na prsou)

až mu chřadlo jeho srdce,

P [Pehr/Pepíček]: to pro své potěšení,

Wildová: nebylo mu souzený. (ukáže nebylo)

(Tanec za ruce ve výši - otočit se)

K: Jednoho myslivce dcera,

Karolína jméno měla,

chodili tam myslivci,

užívat svou regrecí.

(Pepíček chodí kolem a salutuje)

P: A ten mladý mezi nimi, (Pep. ukáže na sebe)

Unterleger se jmenoval,

on s tou dcerou špásoval,

neštěstí se nenadál.

(Pepíček a Karolína tleskají si do rukou a tancují)

W: Do světničky za ní vešel,

pistoli tam ležet našel,

která v lůžku ležela,

ostře nabitá byla.

(ženy udělají vrátka, Pepíček vchází, očistí si boty - ukáže).

K: On pistoli do ruky vzal, že nabitá se nenadál,

on k ní trpce promluvil,

P: ba já bych ji zastřelil.

(Pepíček míŕí, Karolína klečí)

W: Ona na to nic neřekla,

K: Ježiš Maria vykřikla, (vstane)

W: třri kroky udělala, ubohá na zem padla.

(Karolína zdvihne ruce nad hlavu sepjaté (k srdci), Pepíček střîlí, žena dřepne)

29 Písmeno M pravděpodobně označovalo herečku Alexandru Máchovou, která byla nahrazena kolegyní Berkovou, písmeno W Marii Wildovou a P Josefa Pehra. 


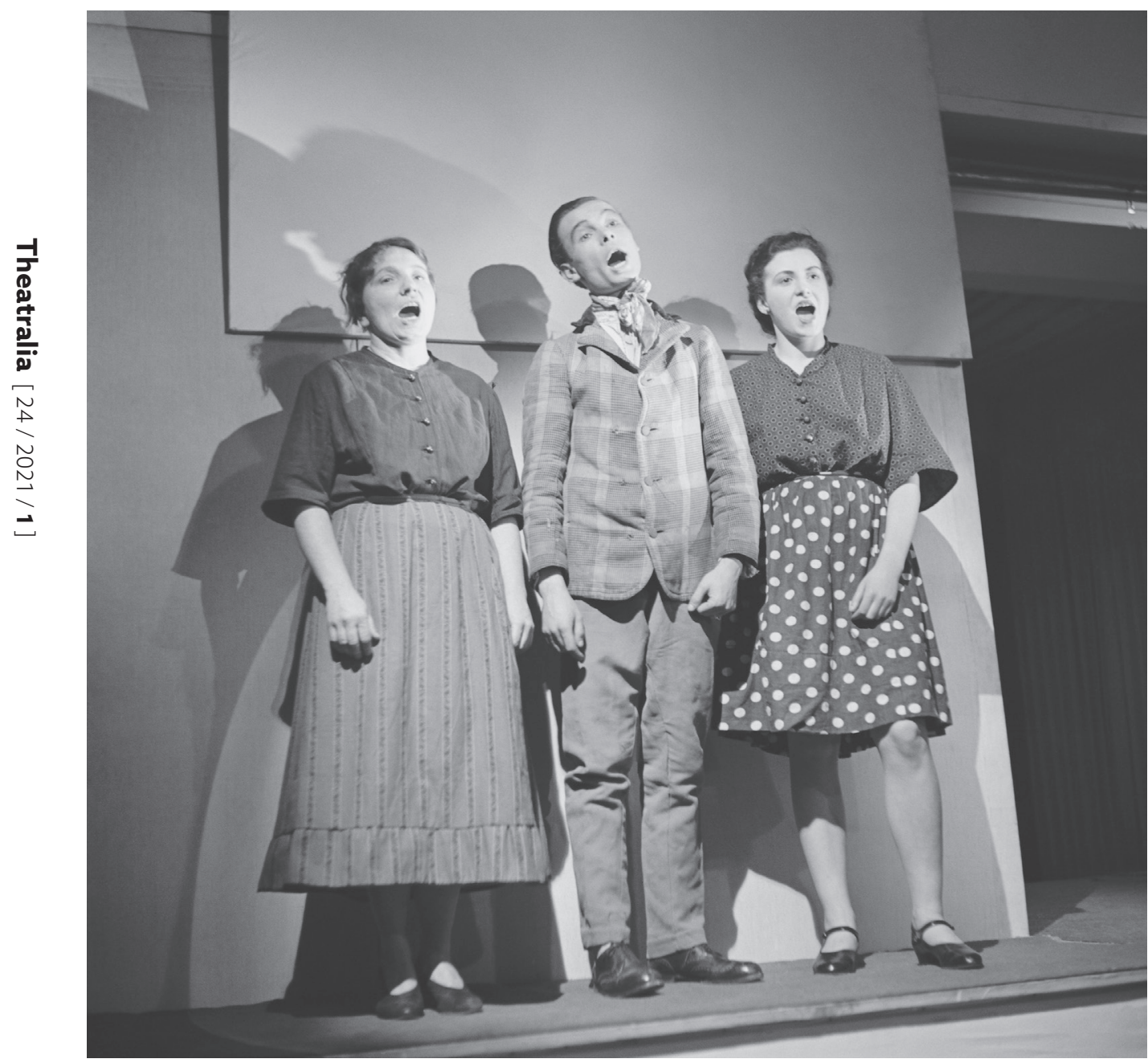

Obr. 17: Píseň o vraždě krásné Karolíny (Alexandr Paul, Archiv atelieru Paul)

P: To bylo pláče, naříkání,

vo to děvče velmi krásný,

otec rukama lomil,

Bože, cos to učinil.

(leží, Pepíček lomí rukama, žena stojí nad mrtvou). (PJH 23/023a-IIb: 35)

Spojením textu písně s hercem (resp. herci), kostýmem, gestem a pohybem změnil zde kramářskou píseň ve zdivadelněné vyprávění. I v této písni - obdobně jako v písni předchozí - se objevil vypravěč, resp. vypravěči, kteří vyprávěli o někom třetím, ale zde zároveň tohoto třetího předváděli; nestáli vně příběhu, stali se jeho součástí. Slova, gesta, výraz a pohyb vypravěčů-postav nebyly pouze ilustracemi k vypravování, naopak 


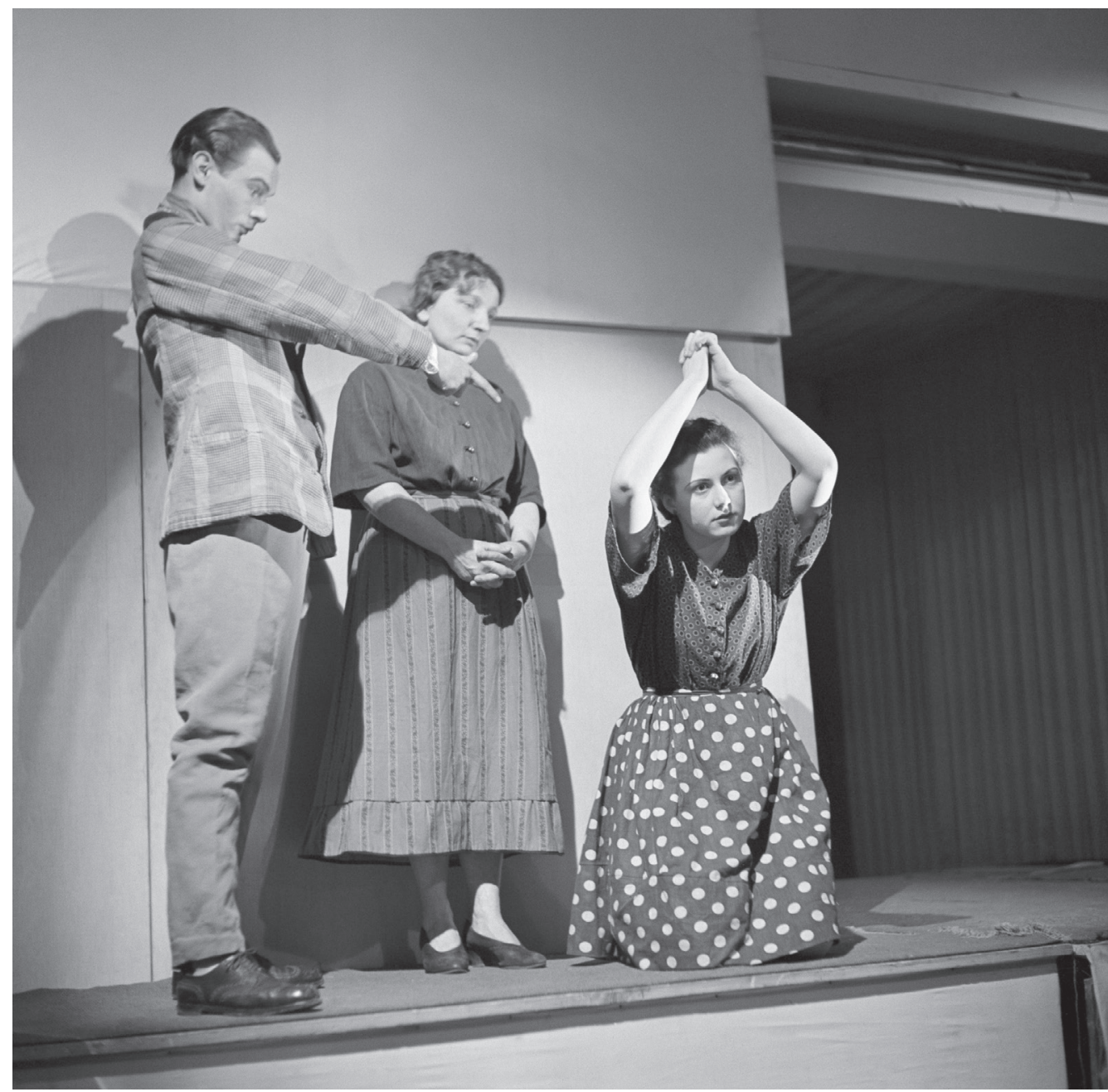

Obr. 18: Píseň o vraždě krásné Karolíny (Alexandr Paul, Archiv atelieru Paul)

vypravování jako by se v Honzlově podání stalo pouhými vysvětlivkami či komentáři $\mathrm{k}$ předváděnému.

\section{„Stesk, bída a beznaděje ${ }^{6630}$}

V druhé části programu Honzl představil písně sociálně laděné. Zaměřil se na skutečnosti pobělohorského období, jež ztěžovaly život lidu: robota, přírodní pohromy (potopa) a válka.

První píseň - „Píseň kratochvilná“ - představuje lyrický monolog sedláka, který si v hospodě stěžuje druhovi na robotu a kontribuce uvalené na lid vrchností. Honzl 


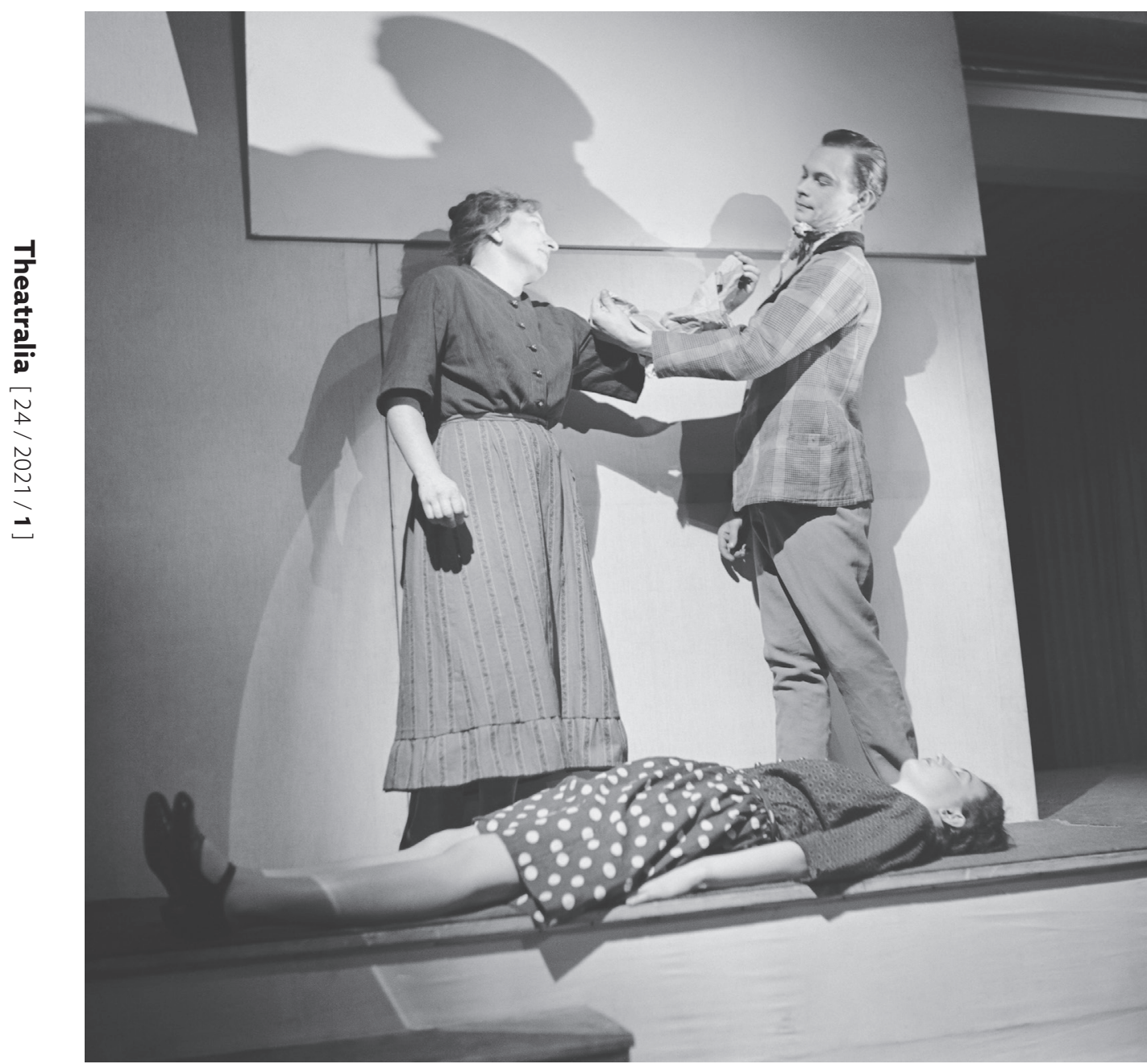

Obr. 19: Píseň o vraždě krásné Karolíny (Alexandr Paul, Archiv atelieru Paul)

monolog rozdělil mezi sedláky dva, nicméně dialogizací nevznikl dramatický dialog založený na významových zvratech a napětí mezi mluvčími, ale dialogizovaný monolog, nebot' oba prezentovali stejný názor, stěžovali si na shodnou životní situaci.

V souladu s atmosférou písně volil Honzl kostýmy, které byly „selské otrhané“, a scénické předměty, jež tvořil „hospodský věnec, stůl, dvě židle dva džbánky“ (PJH 23/023a-IIb: 10). Kromě robotníků v písni účinkovaly - obdobně jako v třetí písni - tři ženy, které přišly na scénu za sborového zpěvu, účastnily se jevištního dění (např. usedly na místa mužů, vzaly jim džbány, přijaly od nich růži apod.) a naslouchaly jejich stížnostem (PJH 23/023a-IIb: 10-11).

Poměry poddaných v 18. století byly představeny nejen písní, ale i předcházejícím komentářem, jenž se opíral o citace z litomyšlských urbářů sebraných Josefem Mikšíčkem. 


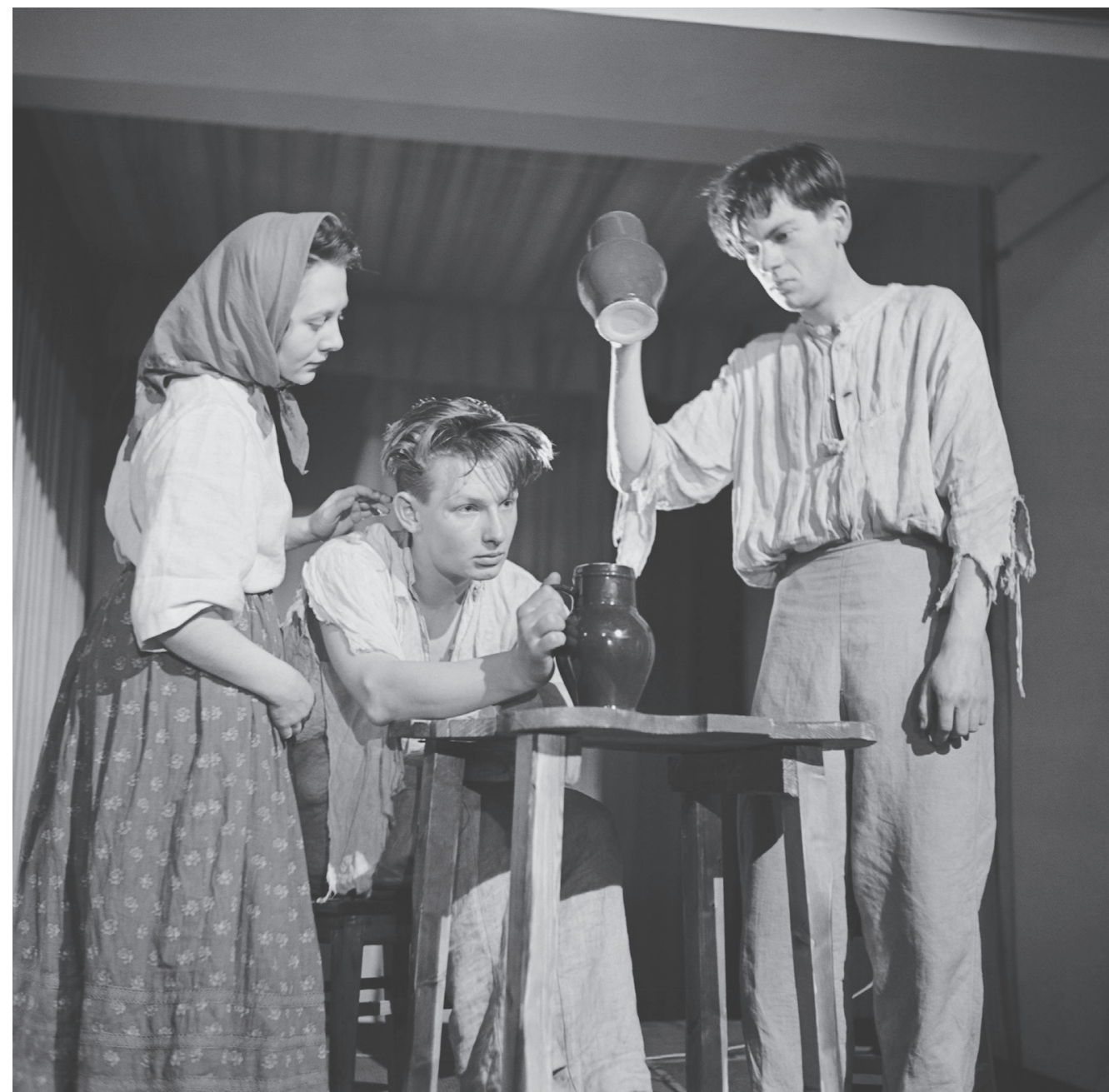

Obr. 20: Píseň kratochvilná (Alexandr Paul, Archiv atelieru Paul)

Záznamy z urbářů zachycovaly pohledem kronikáře a prostřednictvím statistik stejné skutečnosti, o kterých se v písni zpívalo. Prezentovaly téma písně z jiné perspektivy, kontextualizovaly a autentifikovaly emotivní pohled robotníků. ${ }^{31}$

Téma války a jejích dopadů na společnost představil Honzl prostřednictvím „Lamentací tureckého vezíra“. V písni se zpívá o turecké válce, která byla neúspěšně vedena z podnětu pyšného vezíra, jenž si chtěl podrobit křestany, ale byl jimi poražen u Vídně a s ostudou se musel vrátit domů, do Konstantinopole.

31 V porovnání s komentářem ke stejné písni z roku 1946 vyvstane, jak silně protiněmecky měl komentár působit. Téměř před každým výrazem „vrchnost“ je dopsáno „německá“ a před slovy „poddaný“, „lid“, „selský“ je připsáno adjektivum „český“. Takovéto explicitní narážky si v roce 1941 nemohl Honzl dovolit a spoléhal na schopnost diváků číst mezi řádky (PJH 49/049II režisér: 11-13). 


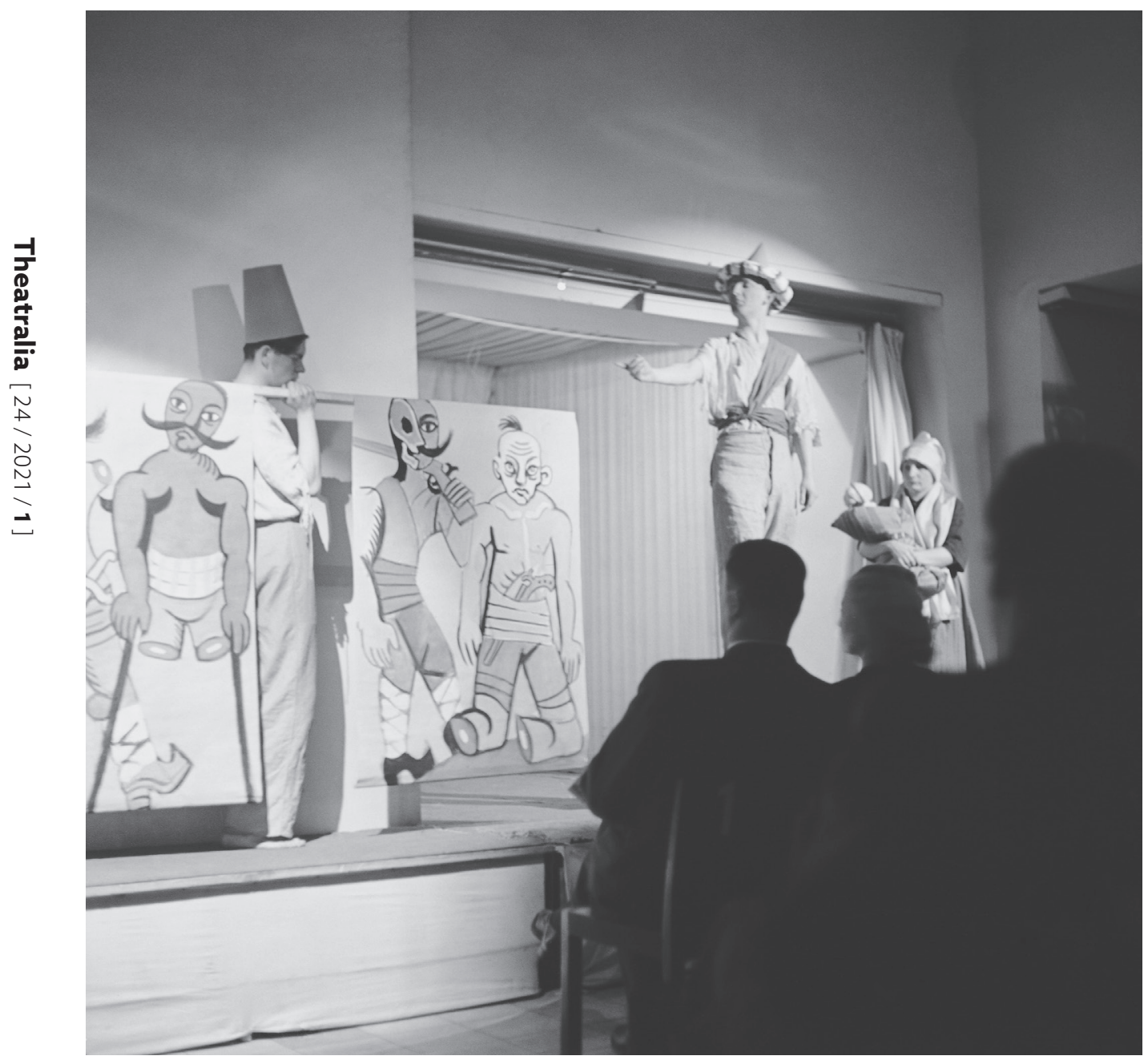

Obr. 21: Píseň o turecké válce (Alexandr Paul, Archiv atelieru Paul)

Formálně tato píseň představuje lyrický monolog rozdělený mezi několik postav: Velký vezír Mustafa Bašta vracející se z prohrané války, Žena velkého vezíra, turecké vojsko a Mufti, nejvyšší turecký kněz. Dialogickým (resp. polyfonním) charakterem monologu nevzniká konflikt mezi mluvčími, ale jeho prostřednictvím je píseň gradována ve smyslu, komu všemu vezír svou pýchou a válečnou nenasytností ublížil (VELTRUSKÝ 1994: 73). Píseň vrcholí výstupem tureckého soudce, jenž pronáší rozsudek smrti nad vezírem. Honzl originální dialogizaci písně zachoval, pouze některé sloky zkrátil, jiné zkombinoval či vypustil.

V souvislosti s Honzlovým inscenačním přístupem hovoří Vyskočil o této písni jako o malé tragédii, kterou hráli lidoví herci (VYSKOČIL 1961: 170). Domnívám se, že ve způsobu inscenování písně jako lidového divadla, tj. jako „hry na tureckou válku“, 


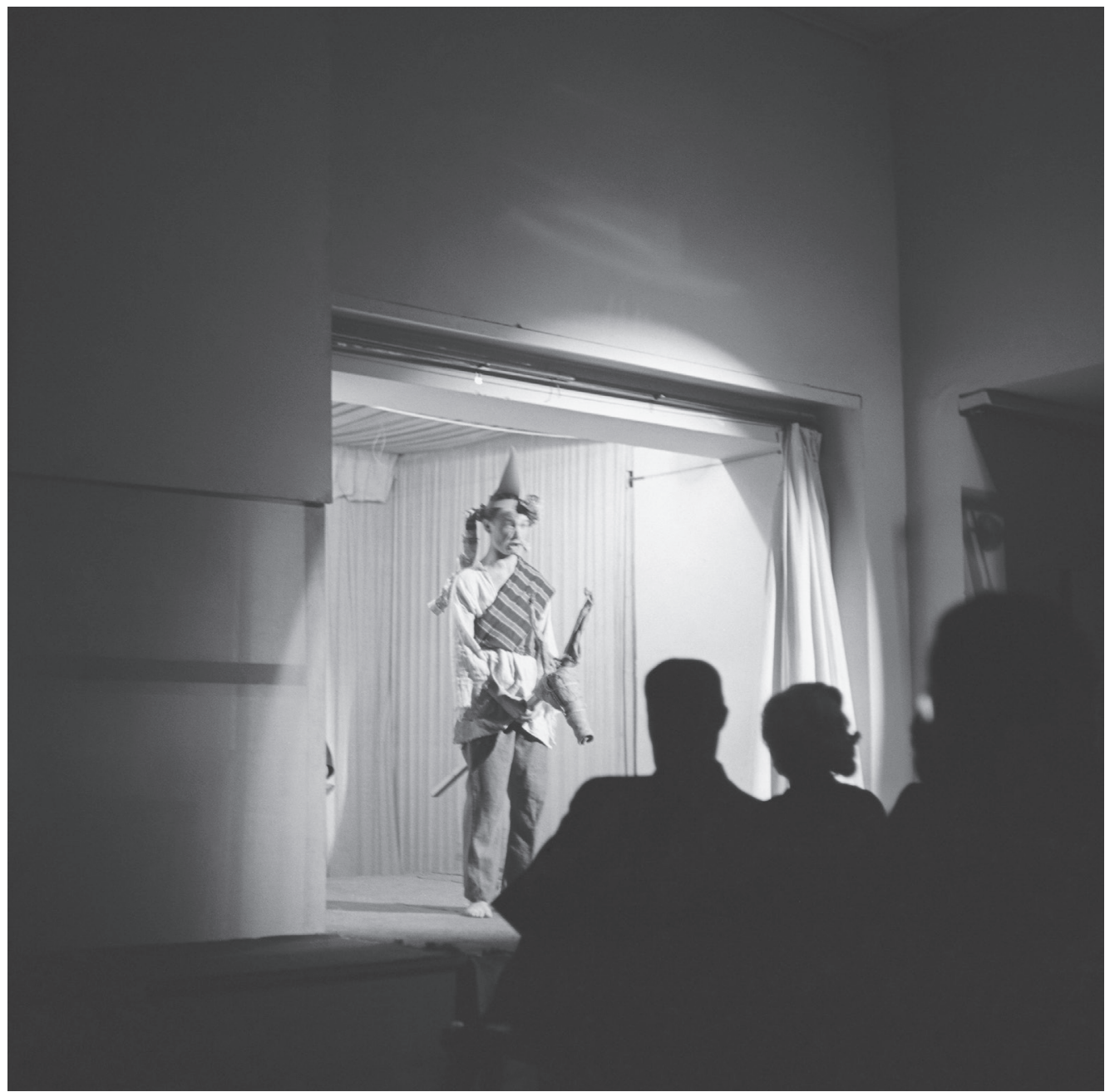

Obr. 22: Píseň o turecké válce (Alexandr Paul, Archiv atelieru Paul)

hrála důležitou roli píseň o sedlácích, nebot „Lamentace“ působily jako by byly sehrány robotníky (Stránský, Vyskočil) z „Písně kratochvilné“, kteří si na selský oděv oblékli primitivně vyhlížející turecké atributy: turban, fez, šerpa apod.

Z uměleckých postupů lidového divadla vycházela i volba rekvizit a způsob jejich zapojení do jevištní akce. Vezír se vracel z války na oslu, který podle vzpomínek Vyskočila „připomínal dětského koníka (koňská hlava na tyči) [...]. Hlava byla vyrobena z juty, uši byly na gumě (VYSKOČIL 1961: 170). ${ }^{32}$ Vezírova žena držela v ruce dětátko, primitivní loutku bez vyznačeného obličeje, v zavinovačce. Sultánův posel - nesoucí zprávu o rozsudku smrti nad vezírem - byl představován dřevěným koníkem s jezdcem (VYSKOČIL

32 V Honzlových poznámkách nicméně stojí, že se jednalo o kozu s ušima. Dle jeho poznámek měl vezír ještě držet v ruce šavli (PJH 23/023a-IIb: 18). 
1961: 170). Sultánovo vojsko zmrzačených vojáků bylo vyobrazeno na obrazové tabuli ve stylu lidových obrazů na skle nebo jarmareční obrazové tabule (konotující taktéž dobové kresby a fotografie válečných invalidů), kterou nesl na rameni jejich druh - „robotník"s fezem na hlavě.

$\mathrm{S}$ poetikou lidového divadla souvisel i způsob realizace jevištní akce, ta by se dala charakterizovat jako do jisté míry statická. Jednotlivé postavy přicházely na scénu, pronášely svůj part za doprovodu gest, mimiky a pohybu v prostorových intencích jeviště. Např. při šesté sloce vyšla před jeviště vezírova žena, otočila se k vezírovi, položila dítě, šla k vezírovi, tahala osla za uši, při sedmé sloce se vezír otočil, při osmé sloce vezír odešel, přišlo vojsko, při deváté sloce žena ukazovala na vojáky, kteří naříkali, atd. (PJH 23/023a-IIb: 19).

Způsobem, jakým Honzl v Lamentacích (ale i v písni o Karolíně a ve „Svatební košili“), využíval prostoru, herecké souhry, náznaku děje, kostýmu a rekvizit, demonstroval, že z kramářského výstupu jednoho herce lze učinit lidové divadlo v pravém slova smyslu.

\section{Světlo a barvy}

Při jednotlivých písních nechával Honzl nasvěcovat scénu barevnými reflektory: modrým, bílým, žlutým a červeným. „Píseň kratochvilná“ byla nasvícena modře, v písni o smrti se střídal bílý a modrý reflektor, v milostné „Písni pro mládence a panny“, která pravděpodobně nebyla uvedena v premiérové montáži, bylo použito žluté osvětlení. Zdá se, že nejkomplexněji bylo použito světla v „Lamentacích“. Ve slokách, které zpívala/recitovala vezírova žena, bylo jeviště nasvíceno bíle, v sloce, při které přijížděl na scénu posel (koník), modře a závěrečná část, kdy se zpívalo o vezírově popravě, žluto-červeně.

Ve svém článku „Možnosti a zákony jevištního výtvarnictvi““ Honzl uvádí, že používal „světla tam, kde malíř používal barvy“ (HONZL 1937:152). Pokud bychom jeho tvrzení vztáhli na $\check{C} P K$, lze barevná nasvícení scény chápat jako transpozici barev lidových obrázků na skle a jarmarečních tabulí, ale také v souvislosti s gotickou/barokní symbolikou barev, jež pronikala nejen do oborů vizuálních (např. malířství), ale i jazykových (literatura, např. Legenda o svaté Kateřině). Honzl tento charakteristický rys lidové/barokní poetiky modernizoval, převedl do jednoho z divadelních vyjadřovacích prostředků (osvětlení), jímž se pravděpodobně pokoušel komunikovat významy spjaté s danou barvou v barokním/lidovém umění. Např́íklad nasvícení závěrečné scény v „Lamentacích“ červeně lze vnímat v souvislosti s „emotivní barevností“ kramářských tabulí: např. masivní použití červené barvy ve výjevech vraždy (WINTER 2019: 252). V případě neuvedené „Světské písně“, jejímž tématem je nevěra milého a opuštění milé, měla být herečka nasvícena žlutě. V tomto případě mohla volba barvy vycházet z (barokní) symboliky barev: žlutá - zrada (barva Jidáše), nevěra apod.

Kromě schopnosti jevištního osvětlení měnit barvu Honzl využíval i jeho schopnosti měnit tvar (např. střídání úzkého a širokého světelného kužele pro osvícení různých 
postav) a intenzitu. Prostřednictvím těchto jednoduchých světelných efektů zkombinovaných se složitějšími - světelnou diapozitivní projekcí a stínohrou - Honzl testoval různé způsoby, jakými světlo může modelovat jevištní dění do esteticky působivé podoby a podílet se na významové výstavě inscenace. ${ }^{33}$

\section{Motivy a leitmotivy}

V průběhu celého pásma lze vysledovat motivy, které se opakují. Nejmarkantnější jsou samozřejmě variace motivu Smrti, která byla hlavní hrdinkou pásma a objevovala se téměř ve všech písních. Mezi další motivy patří například růže - oblíbený lidový symbol, symbol Panny Marie, který se objevil na obrázcích na skle (píseň o Panně Marii), jako součást kostýmu vypravěčky („Svatební košile“) nebo rekvizita - dar pro dívku (píseň o sedlácích). Dále lidové zpodobnění madony s Ježíškem v zavinovačce (píseň o Panně Marii) rezonovalo s postavou vezírovy ženy chovající taktéž dítě v zavinovačce (píseň o turecké vojně). Herci, loutky a postavy zachycené na obrazech/kresbách prováděli stejná gesta (lomili rukama, otáčeli hlavou, křížili ruce na prsou atd.). Nasnadě je napřr. paralela mezi zemřelou Karolínou ležící na zemi a Němcovou kresbou zemřelé cizoložnice nebo mezi závěrečnou scénou loutek - dívky a kostlivce - objímajících se v hrobě („Svatební košile“) a diapozitivem svatebního tance Smrti v písni první. Prostřednictvím opakování/variací stejných motivů v průběhu celého pásma Honzl provazoval jednotlivé výstupy, přispíval ke koherenci montáže a vytvářel překvapivé významové souvislosti mezi písněmi.

Usouvztažněním motivi̊ Honzl nadto odkrýval „skryté umělecké spojitosti všech lidových žánrư“ (HONZL 1964a: 66). Ty se - podle Honzla - shodovaly nejen ve výběru motivů, ale též převážně ve způsobu jejich ztvárnění, tj. v poetice, která bývá charakterizována jako naivní, jednoduchá, hravá apod. (HONZL 1964a: 66). V tomto směru Honzl navazoval na své večery poezie (např. Večer poezie 1900, Cizinci o Praze, Večer s Vitězslavem Nezvalem), v nichž prostřednictvím montáže poukazoval na paralelu mezi poezií a výtvarnictvím. Např. ve Večeru s Vitězslavem Nezvalem odkrýval vztah mezi moderní poezií a surrealistickými obrazy, ve Večeru poezie 1900 mezi motivy/technikou symbolistní poezie (Březina, Sova, Hlaváček, Neumann etc.) a secesního malírství (Bílek, Stretti, Preissler a další). Spojitost byla nadto teoretizována v přednášce Jana Mukařovského pronesené v rámci Večera poezie. V podstatě lze říci, že Mukařovský zde byl nositelem odborné roviny, kterou Honzl později integroval do svých montáží. V C̆PK tuto rovinu přebral komentátor, který (mimo jiné) naznačoval paralely mezi poezií, výtvarnictvím a divadlem.

Prostřednictvím motivů a jejich uměleckého provedení Honzl upozorňoval nejen na shody mezi různými oblastmi lidového umění, ale také na odlišnosti lidového umění

33 Z tohoto pohledu navazoval na své předchozí inscenace, jako např. Učitel a žák (1927), Peruánský kat (1929), Androkles a lev (1930), Donogoo Tonka (1931), ve kterých využíval světelných efektů, a ověřoval v praxi své úvahy z oblasti zapojení světla do divadelního artefaktu. Kromě „Možností jevištního výtvarnictví“ se světlem zabýval i v „Prostorových problémech divadla“ (1933/1934), „Pohybu divadelního znaku“ (1940) atd. 
od umění „vysokého“. Tuto rozdílnost akcentoval nejvýrazněji v prvních třech písních pásma, v nichž proti sobě stavěl literární a výtvarné ztvárnění stejných motivů (smrti, nevěry apod.) ve „vysokém“ a lidovém umění. Konfrontací Honzl poukazoval na to, že stejné motivy se objevují jak ve „vysokém“, tak lidovém umění; že lid přebíral z „vysokého“ umění (témata, motivy), ale přetvořil je na základě svých estetických a sociálních norem/podmínek, jež byly zcela odlišné od „panských“ (PJH 49/049II režisér: 2). Lidové umění tak představovalo pro Honzla na jedné straně hodnotu estetickou, na druhé společenskou; považoval ho za svébytnou a inspirativní uměleckou formu a - v souladu s dobovým diskursem - za prostředek, kterým se český lid 17.-18. století vymezoval vůči (cizí, německé) šlechtě a uchovával svou kulturu a jazyk. ${ }^{34}$

V tomto směru lze Honzlovo pásmo považovat za příspěvek k odhalení povahy českého baroka (lidové baroko vs. baroko paláců), jímž se v 30. letech - zejména v souvislosti s výstavou „Pražské baroko“ (1938) - zabývalo mnoho odborníků a umělců, jako např. Zdeněk Kalista, Karel Šourek, Josef Vašica nebo Emil František Burian.

\section{Odvážná spojení}

Pro Honzlovu tvorbu bylo př́iznačné, že využíval rozličných jevištních prostředků jako „znak[u] skutečnosti, ukazující[ch] [...] k zobrazovanému předmětu samotnému a skrze něj současně i k věcem jiným“ (SRBA 2004: 53). Honzlovými slovy, to, co bylo prezentováno na scéně, mělo schopnost „přitahovat představy o skutečnostech z nejvzdálenějších asociací a z nejvzdálenějších krajů našich vzpomínek“ (HONZL 1956: 261). Na tomto principu vytvářel ve 20. letech složité - divákům těžko srozumitelné - jevištní metafory, které byly vedeny snahou po experimentátorství a které byly pokusem aplikovat principy poezie (poetismu) na divadelní scénu (více OBST a SCHERL 1962: 99-101). Ve 40. letech mu byly metaforické obrazy, přenesené významy a spoje převážně prostředkem, jímž se mohl vyjadřovat k politické a společenské situaci své doby, aniž byla inscenace zakázána censurou. V ČCK vytvořil mnoho odvážných spojení mezi tématy písní, barokním světem a svou současností; v centru jeho zájmu byla válka, německá okupace a jejich dopady. ${ }^{35}$

Kromě paralely mezi dobyvačností tureckého vojska a vojska německého, mocichtivostí vezíra a Hitlera, na kterou upozorňuje Srba (SRBA 1988: 85), a politické roviny Daumierova obrazu, o které jsem hovořila výše, zde nacházíme řadu dalších spojů. Např. v prvních dvou písních se Honzl velice pravděpodobně opíral o dobové vnímání války jako pekelných muk a tance Smrti a zpodobnění německých/fašistických vojenských jednotek (a jejich vůdců) jako Smrtek. Takovéto pojetí války a vojáků lze najít

34 „[...] písně českého lidu selského [nám byly] vzorem pro umění, které se nechce popanštit [...]. Z písní tohoto lidu dýchala síla, která nelze ničím zlomit ani vyvrátit.“ (PJH 49/049II režisér: 2)

35 Výstupy komentátora z roku 1946 některé spojitosti původní inscenace odhalují. Např.: „Stránský představoval sedláka, který nářkem nad robotou probouzel vzpouru. Zpíval - bylo to v dobách nacistického útlaku - o touhách a nadějích prostého lidu, úpějícího pod panskými karabáči a uchovávajícího své češství i v dobách největší robotnické bídy a strádání“ (PJH 49/049II režisér: 2). 
např. v poezii S. K. Neumanna, Fráni Šrámka, v esejích Karla Čapka, v politických kresbách Josefa Čapka (cyklus kreseb nazvaných Modern Times nebo Diktátorské boty), Emila Filly (Německá muzika a ruská tanečnice, Noční šepot na hrobech), Antonína Pelce (Carmen či Seňorita Franca), jež se objevovaly v průběhu 30. let v dobovém tisku (např. v Lidových novinách), atd.

Lze se domnívat, že i píseň o Panně Marii obsahovala aktuální podtext. Panna Maria byla tradičně považována za ochránkyni českých zemí; byla jí připisována ochrana země (měst) před cizími vojsky (Tatary, Švédy atd.) a dalšími nebezpečími (ROYT 2011: 54). V druhé polovině třicátých let - v obavách o existenci národa - zesílila četnost procesí k mariánským poutním místům, jež získávala silný manifestační charakter a jež byla pod dohledem Němců. V dobovém kontextu mohla píseň (inscenována jako procesí) působit jako vyjádření prosby o ochranu (záchranu) země před okupanty.

Díky těmto (a mnoha dalším) spojením představují České pisně kramářské v kontextu Honzlovy tvorby pro D 99 společensky a politicky nejvyostřenější inscenaci. Honzl zde vynalézavým zpơsobem využil primární - zpravodajské - funkce kramářské písně k tomu, aby „přinesl“ „truchlivé noviny“ o tom, co se děje kolem (HONZL 1964b: 82).

\section{„Již jsem vám moje verše zcela přezpíval“ aneb závěrem}

Honzl koncipoval své ČPK jako montáž, jejímž záměrem bylo podat co nejširší a nejpestřejší obraz o jarmareční písni. Volba montáže měla i praktický aspekt, nebot umožňovala měnit pořadí písní, některé z programu vyloučit (např. ty, které neměly u diváků velký ohlas nebo bylo problematické jejich inscenování, jako „Píseň o povodni“) a nahradit je jinými. Těmito úpravami vznikly po významové a formální stránce tři odlišné podoby $\breve{C} P K$. První v roce 1941, druhá v roce 1946 a třetí v roce 1961, která je nejznámější, ale nikdy nebyla inscenována; vznikla pouze pro potřeby dvou různých edic.

Přes své odlišnosti, které pramení nejen z vnitřních - režisérských/edičních - záměrů, ale i z vnějších - dobových okolností (válečné vs. poválečné uvedení), je za všemi třemi verzemi patrná Honzlova snaha ukázat, že kramářská píseň byla po tematické stránce velice bohatá, měla mnoho forem, poloh a odstínů, skýtala nesčetné množství možností, jak ji uchopit - ozvláštnit - a přepracovat pro moderní divadelní scénu. Honzl v nich nabídl neotřelý pohled na tuto písňovou/divadelní tradici a jejím prostřednictvím hledal nové prostředky dramatičnosti a divadelnosti, upozorňoval na paralely mezi moderním uměním a uměním barokním, stejně jako na problémy doby pobělohorské a doby své. Stručně řečeno, Honzl vřadil kramářskou píseň do složité sítě společenských, uměleckých, politických a odborných vztahů, jež formovaly její podobu a (aktualizovaly) její významy. 


\section{Bibliografie}

-a-. 1946. Ty, který tu zpíváš nyní. Zemědělské noviny (15. 5. 1946).

Archiv Atelieru Paul (AAP). Sbírka Divadla, Divadlo 99 u Topičů/ Kramářské písně, e. č. 39372/1-9. BENEŠ, Bohuslav. 1971. Dramatické prostředky kramářských písní 19. století. In Otázky divadla a filmu II. Brno: Universita J. E. Purkyně, 1971: 101-126.

BERÁNEK, Jaroslav (ed.). 1961. Divadlo poezie. Praha: Orbis, 1961.

BRABEC, Jan et al. 1983. Dějiny českého divadla. IV. Činoherni divadlo v Československé republice a za nacistické okupace. Praha: Academia, 1983.

DVOŘÁK, Antonín. 1964. Vzpomínky na Honzlovo Divadélko pro 99 a počátky Divadélka ve Smetanově muzeu. In Milan Obst (ed.). Divadélko pro 99. Praha: Orbis, 1964: 214-222.

ERBEN, Karel, Jaromír. 1864. Píseň č. 250 (Loučení). Prostonárodni české písně a řikadla. Praha: J. Pospísili, 1864: 403. e-knihovna MLP.

HONZL, Jindřich. 1937. Možnosti a zákony jevištního výtvarnictví. In Tentýž. Sláva a bída divadel: režisérưv zápisnik. Praha: Družstevní práce, 1937: 151-152.

HONZL, Jindřich. 1956. Slovo na jevišti a ve filmu. In Tentýž. K novému významu uměni. Praha: Orbis, 1956: 197-221.

HONZL, Jindřich. 1964a. České písně kramářské v Divadélku pro 99. In. Milan Obst (ed.). Divadélko pro 99. Praha: Orbis, 1964. 65-66.

HONZL, Jindřich. 1964b. České písně kramářské. In. Milan Obst (ed.). Divadélko pro 99. Praha: Orbis, 1964. 67-98.

KOMENSKÝ, Jan Amos. 1941. Orbis pictus. Praha: Fr. Borový, 1941.

LAUGHTON, Bruce. 1996. Honoré Daumier. New Haven: Yale University Press, 1996.

mat. 1941. Večer Českých písní kramářských v Divadélku pro 99. Lidové noviny (12. 3. 1941).

MELNIKOVÁ-PAPOUŠKOVÁ, Naděžda Filaretovna. 1938. Československé lidové maliřství na skle = Imagerie eglomisé populaire tchécoslovaque. Praha: Státní grafická škola, 1938.

NEJEDLÝ, Zdeněk (N.Z.). 1941. Honzlův soubor u Topičủ. Pásmo z kramářských písní. A-Zet (10. 3. 1941).

MIKŠÍČEK, Josef. 1939. Z dob selských bouři. Choceň: nákladem vlastním, 1939.

NOVOTNÝ, Miloslav (ed.). 1940. Špalíček písniček jarmarečních. Praha: Evropský literární klub, 1940.

OBST, Milan a Adolf SCHERL. 1962. K dějinám české divadelni avantgardy: Jindřich Honzl, E. F. Burian. Praha: Nakladatelství Československé akademie věd, 1962.

OBST, Milan (ed.). 1964. Divadélko pro 99. Praha: Orbis, 1964.

Pozůstalost Jindřicha Honzla (PJH). Diapozitivy - negativy 2, bez ev. č. Diapozitivy pro České písně kramářské.

Pozůstalost Jindřicha Honzla (PJH). Scénáře a výpisky, složka 111, e. č. 111d. Scénáře k národopisnému filmu o svatbách ve Velké nad Veličkou (strojopis).

Pozůstalost Jindřicha Honzla (PJH). Rukopisy o Majakovském, aj., složka 29d, e. č. 029d-VI. Rukopisné poznámky o obřadu.

Pozůstalost Jindřicha Honzla (PJH). Divadélko pro 99, složka 23a, e. č. 023I-PK. České písně kramářské, rukopis nehraného II. a III. dílu.

Pozůstalost Jindřicha Honzla (PJH). Divadélko pro 99, složka 23a, e. č. 023I-PK. České písně kramářské, scénické návrhy 9 listů.

Pozůstalost Jindřicha Honzla (PJH). Divadélko pro 99, složka 23a, e. č. 023a-IIb. České písně kramářské - režie a inspicie. 
Pozuistalost Jindřicha Honzla (PJH). Divadélko pro 99, složka 23a, e. č. 023a-IIc. České písně kramářské, text - rukopis.

Pozůstalost Jindřicha Honzla (PJH). Divadélko pro 99, složka 23a, e. č. 023a-IId. České písně kramářské (text - strojopis) - světla.

Pozůstalost Jindřicha Honzla (PJH). Divadélko pro 99, složka 23a, e. č. 023-VI, programy.

Pozůstalost Jindřicha Honzla (PJH). Divadélko pro 99, složka 23a, e. č. 023-II, notový materiál, výstřižky.

Pozůstalost Jindřicha Honzla (PJH). Studio Národního divadla, složka 26b, e. č. 026b, In memoriam Zdeňka Stránského - Ty, který tu zpivuáš nyni, plakát.

Pozůstalost Jindřicha Honzla (PJH). J. Hora, Z. Stránský, složka 49, e. č. 049II. Ty, který tu zpíváš nyní - režisér.

Pozůstalost Jindřicha Honzla (PJH). J. Hora, Z. Stránský, složka 49, e. č. 049II. Ty, který tu zpíváš nyní - hudba.

Pozůstalost Jindřicha Honzla (PJH). J. Hora, Z. Stránský, složka 49, e. č. 049II. Ty, který tu zpíváš nyní - censura.

ROYT, Jan. 2011. Obraz a kult v Čechách 17.-18. století. Praha: Karolinum, 2011.

SMETANA, Robert a Bedřich VÁCLAVEK (edd.). 1937. České písně kramářské. Praha: Fr. Borový, 1937.

SRBA, Bořivoj. 1988. O nové divadlo: nástup nových vývojových tendencí v čes. divadelnictví v letech 1939-1945. Praha: Panorama, 1988.

SRBA, Bořivoj. 2004. Řeč světla: princip světelného divadla v inscenační tvorbě Emila Františka Buriana. Brno: Janáčkova akademie múzických umění v Brně, Divadelní fakulta, 2004.

Stezky. Knihovna dokumentů estetického tvoření. 1937. In Robert SMetana a Bedřich Václavek. České písně kramářské. Praha: Fr. Borový, 1937. záložka.

VELTRUSKÝ, Jiří. 1994. Kramářské písně a dramata. Příspěvky k teorii divadla. Praha: Divadelní ústav, 1994: 69-73.

VYSKOČIL, Stanislav. 1961. Doslov. In Jaroslav Beránek. Divadlo poezie. Praha: Orbis, 1961: 167-172.

WINTER, Tomáš et al. 2019. Jdi na venkov!: výtvarné uměni a lidová kultura v českých zemích 18001960. Řevnice: Arbor vitae societas, 2019.

ŽDYCHOVÁ, Dagmar. 2012. Nekonvenční divadelní scéna U Topičů. In Milan Pech (ed.). Topičưv salon 1937-1949. Praha: Společnost Topičova salonu, 2012: 28-45. 


\section{Mgr. Eva Šlaisová, Ph.D.}

Katedra divadelní vědy,

Filozofická fakulta Univerzity Karlovy,

Nám. J. Palacha 2, 11638 Praha 1, Česká republika

eva.slaisova@ff.cuni.cz

Eva Šlaisová získala v roce 2005 magisterský titul z bohemistiky a etnologie na Masarykově univerzitě v Brně (ČR). V roce 2013 zakončila svá doktorandská studia na Katedře slovanských jazyků a literatury na Torontské univerzitě. Její disertační práce The Semiotic Games of Voskovec and Werich's Liberated Theatre (Sémiotické hry Voskovce a Wericha v Osvobozeném divadle) se soustředí na české experimentální divadlo dvacátých a třicátých let ve vztahu k soudobým evropským divadelním trendům a teoriím Pražské školy. Mezi lety 2015-2016 absolvovala post-doktorskou stáž na Štrasburské univerzitě, kde se zabývala výzkumem vztahů mezi francouzskou sociální a kulturní antropologií, pražským strukturalismem a avantgardním uměním, a dlouhodobě spolupracovala s týmem Katedry divadelních studií Masarykovy univerzity v Brně na výzkumném projektu České strukturalistické myšlení o divadle. V současné době působí jako vědecký pracovník na Katedře divadelní vědy Univerzity Karlovy, kde se zabývá výzkumem podporovaným GAČR Primitivní a lidové umění $\checkmark$ české divadelní avantgardě: kontext, praxe, teorie. 